\title{
Guinea: Staff-Monitored Program
}

This paper on the staff-monitored Program for Guinea was prepared by a staff team of the International Monetary Fund as background documentation for the periodic consultation with the member country. It is based on the information available at the time it was completed on June $\mathbf{1}$, 2005. The views expressed in this document are those of the staff team and do not necessarily reflect the views of the government of Guinea or the Executive Board of the IMF.

The policy of publication of staff reports and other documents by the IMF allows for the deletion of market-sensitive information.

To assist the IMF in evaluating the publication policy, reader comments are invited and may be sent by e-mail to publicationpolicy@imf.org.

Copies of this report are available to the public from

International Monetary Fund $\bullet$ Publication Services

700 19th Street, N.W. • Washington, D.C. 20431

Telephone: (202) 6237430 • Telefax: (202) 6237201

E-mail: publications@imf.org • Internet: http://www.imf.org

Price: $\$ 15.00$ a copy

\section{International Monetary Fund Washington, D.C.}




\section{INTERNATIONAL MONETARY FUND}

Guinea

\section{Staff-Monitored Program}

Prepared by the African Department

(In collaboration with other departments)

Approved by David Nellor and Anthony Boote

June 1, 2005

- Guinea's three-year arrangement under the PRGF went off track at end-2002 and expired on May 1, 2004. This was followed by attempts at negotiating a StaffMonitored Program (SMP), which failed because of lack of progress in tackling key macroeconomic imbalances, addressing severe distortions in the exchange rate regime, and implementing the recommendations of the 2002 safeguards assessment mission.

- $\quad$ The SMP mission took place during March 29-April 9, 2005 and was prompted by the authorities' new resolve in addressing macroeconomic imbalances and implementing key structural reforms. The mission met with the Prime Minister, the Minister of Economy and Finance, the Governor of the Central Bank (BCRG), several other Ministers and other key senior officials. The staff team comprised Mr. van den Boogaerde (head), Mr. Nsengiyumva (AFR), Mr. Jones (Resident Representative) and Mr. Barry (Resident Economist). The mission worked closely with a parallel World Bank mission.

- In the attached letter dated May 31, 2005 (Appendix I) and the accompanying memorandum of economic and financial policies, the authorities request a 12-month SMP starting April 1, 2005, to establish a policy implementation track record that could lead to a new PRGF arrangement. The authorities also request that negotiations of a PRGF-supported program be initiated earlier than the allocated 12 months, if future staff assessments indicate that the program objectives have been attained earlier than expected. Contingent upon satisfactory performance under a SMP and a successor PRGF-supported program, and observance of the completion point triggers, the earliest the completion point could be reached is during the last quarter of 2006.

- The next Article IV consultation report, together with the first review of the SMP and a Joint Staff Advisory Note on the authorities' PRSP second annual progress report, is scheduled for Executive Board discussion by end-October 2005. 


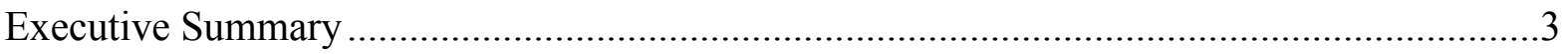

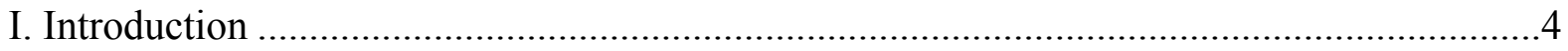

II. Recent Developments and Performance Under the PRGF..............................................4

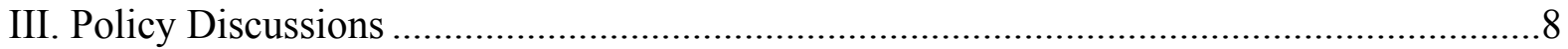

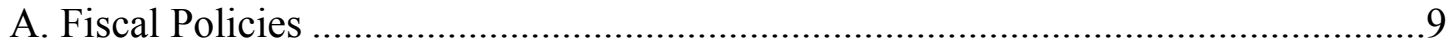

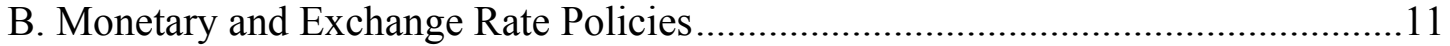

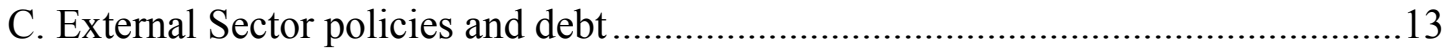

D. Other Structural Reforms and Governance....................................................... 13

E. Poverty Reduction Strategy .......................................................................... 14

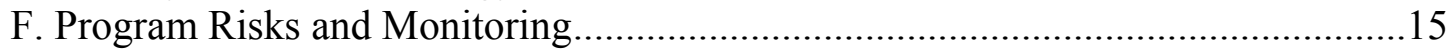

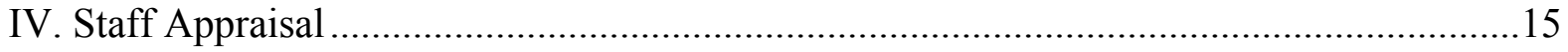

Tables

1. Selected Economic and Financial Indicators, 2002-07 .......................................18

2. Financial Operations of the Government, 2002-2007..........................................19

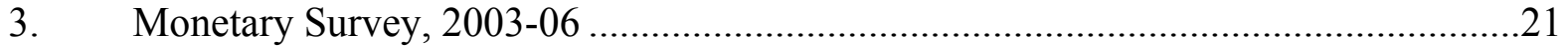

4. Financial Soundness Indicators for the Banking System, 2000-04 .........................23

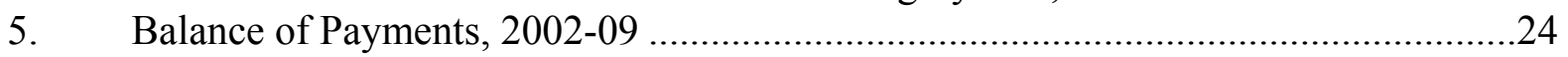

6. Millennium Development Goals.......................................................................26

Appendices

I. Letter of Transmittal and Memorandum on Economic and Financial Polices

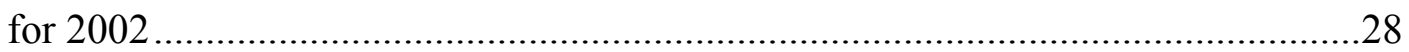

Annex I: Memorandum on Economic and Financial Policies for the period

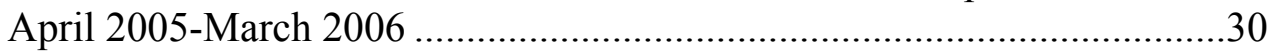

Annex II: Technical Memorandum of Understanding.............................................44

II. Relations with the Fund ................................................................................5

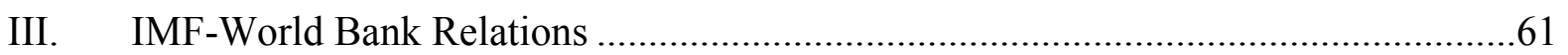




\section{Executive Summary}

- The political environment for reform remains mixed. On the one hand, the attack on the President on January 19 and his declining health continue to cloud the political situation. The security situation remains fragile, notably because of the unsettled situation in Côte d'Ivoire. On the other hand, with clear support from the President, the new Prime Minister has so far successfully pushed for tighter fiscal and monetary policies and the adoption of key reforms, especially the liberalization of the foreign exchange system and the restructuring of the water, telecommunications, and electricity distribution companies. These efforts, notably in reining in the President's profligate spending, are significant as they are taking place in the face of resistance from vested interests.

- $\quad$ Economic performance remained weak in 2004. Real GDP is estimated to have grown by 2.7 percent. Year-end consumer price inflation reached 27.6 percent, essentially reflecting the continuation of large fiscal deficits accommodated by a loose monetary policy, and significant increases in the administered prices of rice, petroleum products, and transportation in mid-August. Net foreign assets of the Central Bank remained negative. Guinea accumulated external arrears to multilateral and bilateral creditors, including frequent short-term arrears to the Fund.

- $\quad$ Fiscal policy was tightened in the first quarter of 2005, but monetary expansion remained significant. The fiscal revenue target was achieved and expenditure commitments remained at a low level, pending the approval of the 2005 budget. Monetary expansion was significantly higher than anticipated due to unsterilized purchases of gold by the central bank and the impact of the exchange rate depreciation on foreign exchange balances.

- $\quad$ Agreement in principle was reached on a staff-monitored program covering the period April 2005 to March 2006. The program would support the authorities' efforts in restoring macroeconomic stability and establish a track record of policy implementation to pave the way for a new PRGF arrangement and subsequently reach the completion point under the HIPC Initiative. The program also includes structural reforms targeted to support macro-stabilization efforts and to lay the basis for stronger and sustained economic growth. The authorities wish, however, that negotiations of a PRGF-supported program be initiated earlier, if future reviews indicate that the program objectives have been attained earlier than the 12 months time frame.

- The program faces a number of risks. Internal political tensions, the fragile security situation at borders, and institutional and capacity constraints may hinder the implementation of the program. Quarterly staff assessments of program implementation and further technical assistance may help mitigate some of these risks. 


\section{INTRODUCTION}

1. On August 27, 2004, the Executive Board concluded the 2004 Article IV consultation and discussed the ex-post assessment (EPA) of the Fund's longer-term program engagement in Guinea. Directors welcomed the emergency economic recovery program adopted by the authorities in March 2004 following the serious deterioration of Guinea's economic situation in 2003. However, they considered that this package alone would not be sufficient to put the economy back onto a solid growth trajectory, nor bring about a significant reduction in inflation. Directors stressed that initiating a SMP would require evidence that the emergency program is restoring fiscal and monetary discipline, as well as the adoption of a flexible exchange rate system, the implementation of the recommendations of the 2002 safeguards assessment mission, and the initiation of urgently needed structural reforms.

2. A staff team that visited Conakry in December 2004 agreed with the authorities on significantly tighter fiscal and monetary policies for 2005 and on minimum requirements for entering into negotiations for a SMP, including: (i) the adoption of the 2005 budget agreed with the staff and evidence of a turnaround tending towards the tightening of fiscal and monetary policies in early 2005; (ii) the liberalization of the exchange rate regime; and (iii) the implementation of the safeguards assessment mission's recommendations. All these conditions were met during the first quarter of 2005.

3. In the attached Letter of Intent and Memorandum of Economic and Financial Policies (Appendix I), the authorities state their commitment to implement an SMP during the period April 2005 to March 2006, as a prerequisite for negotiating a new PRGF-supported program. However, they expressed their wish to initiate the negotiations of a PRGF-supported program earlier than the allocated 12 months, if future staff assessments indicate that the program objectives have been achieved more rapidly.

4. Summaries of Guinea's relations with the Fund and the World Bank Group are presented in Appendices II and III, respectively. Statistical issues remain as presented in the August 2004 staff report (Country Report No. 04/392).

\section{Recent Political and Economic Development}

5. The political and security situation remains uncertain. After an eight month hiatus since the resignation of the previous Prime Minister, Mr. Cellou Dalein Diallo was named Prime Minister on December 9, 2004. With clear support from the President, Mr. Diallo has so far pushed for tighter fiscal and monetary policies and the adoption of key reforms, especially the liberalization of the foreign exchange system and the restructuring of the water, telecommunications, and electricity distribution companies. The political situation continues to be clouded, however, by an attack on the President on January 19 and his declining health. The security situation remains fragile, notably because of the unsettled situation in Côte d'Ivoire. In an attempt to normalize relations with the European Union, the government committed to promote human rights and democracy, liberalize the media, and organize free and transparent municipal elections in 2005 and legislative elections in 2007. 
6. Economic activity remained weak in 2004. Real GDP is estimated to have grown by 2.7 percent, which was nonetheless an improvement over the growth rate of 1.2 percent in 2003. Economic activity benefited from a modest pickup in the construction, public works and service sectors, but continued to be adversely affected by instability in neighboring countries, electricity outages, shortages of cement, and low investment spending by the private sector due to the uncertain internal political environment. Year-end consumer price inflation reached 27.6 percent, essentially reflecting the continuation of large fiscal deficits accommodated by a loose monetary policy, and significant increases in the administered prices of rice, petroleum products, and transportation in mid-August. The external current account deficit (excluding grants) remained around 4 percent of GDP. This deficit was financed

\begin{tabular}{|lrrrr|}
\hline \multicolumn{5}{|c|}{ Selected Macroeconomic Indicators, $2001-04$} \\
\hline & 2001 & 2002 & 2003 & 2004 \\
\hline Real GDP growth (\% change) & 4.0 & 4.2 & 1.2 & 2.7 \\
Inflation, average (\% change) & 5.4 & 3.0 & 12.9 & 17.5 \\
Inflation, end of period ( \% change) & 1.1 & 6.1 & 14.8 & 27.6 \\
Real effective exchange rate (\% change) & -3.0 & -2.3 & -4.3 & -5.7 \\
Terms of trade (\% change) & 7.9 & 2.4 & -2.3 & -10.9 \\
Broad money (\% change) & 14.8 & 19.2 & 35.3 & 37.0 \\
Current account balance (excl. grants \%GDP) & -4.8 & -5.6 & -4.0 & -4.2 \\
Foreign reserves (in months of imports) & 2.7 & 2.3 & 1.6 & 1.2 \\
NPV of external debt to exports & 208.2 & 208.2 & 201.4 & 197.4 \\
Debt service ratio (\% of XGS) & 9.0 & 9.0 & 12.5 & 11.4 \\
\hline
\end{tabular}
largely by an accumulation of external arrears.

\section{The fiscal slippages continued in}

2004. To reflect spending overruns, mostly on account of higher-than-budgeted defense spending, interest charges on domestic debt, and domestically financed investment outlays, the authorities prepared a supplementary finance law in September, aiming at a primary surplus of 1.3 percent of GDP, compared to 1.6 percent in the original budget. ${ }^{1}$ This target was not met. The end-December primary balance, excluding extra budgetary outlays, which had not been budgeted, ${ }^{2}$ was 0.4 percent of GDP lower-than-targeted. The overall fiscal deficit, excluding grants, was

\begin{tabular}{|c|c|c|c|c|c|}
\hline \multicolumn{6}{|c|}{$\begin{array}{l}\text { Central Government Finance, 2001-04 } \\
\text { (In percent of GDP) }\end{array}$} \\
\hline & \multirow[t]{2}{*}{2001} & \multirow[t]{2}{*}{2002} & \multirow[t]{2}{*}{2003} & \multicolumn{2}{|c|}{2004} \\
\hline & & & & $\begin{array}{l}\text { Suppl. } \\
\text { Fin. law }\end{array}$ & $\begin{array}{r}\text { Outurn } \\
1 /\end{array}$ \\
\hline Revenue and grants & 14.7 & 13.8 & 13.2 & 12.4 & 11.6 \\
\hline Revenue & 11.3 & 12.0 & 10.5 & 10.9 & 10.5 \\
\hline Mining & 2.8 & 2.3 & 1.5 & 1.9 & 1.9 \\
\hline Nomining & 8.5 & 9.8 & 9.0 & 9 & 8.6 \\
\hline Expenditure and net lending & 18.8 & 18.3 & 19.2 & 15.6 & 16.5 \\
\hline Primary current expenditure & 10.1 & 10.6 & 10.8 & 7.8 & 8.9 \\
\hline Capital expenditure & 7.2 & 5.8 & 6.3 & 5.4 & 5.0 \\
\hline Primary balance & 0.6 & 0.0 & -2.5 & 1.3 & 0.9 \\
\hline Overall balance, incl.grants & -4.1 & -4.4 & -6.0 & -3.2 & -3.5 \\
\hline Overall balance, excl. grants & -7.5 & -6.2 & -8.8 & -4.6 & -4.5 \\
\hline Bank financing & 0.4 & 3.6 & 3.8 & 1.7 & 2.7 \\
\hline Change in arrears & -0.1 & -0.9 & 1.1 & 0.6 & 1.5 \\
\hline
\end{tabular}
close to the target of 4.6, due to lower-than-anticipated externally financed investment

\footnotetext{
${ }^{1}$ This supplementary budget took into account the spending overruns incurred by that date and cut budgetary allocations for nonpriority spending to minimize the deterioration in the overall balances.

${ }^{2}$ These extra budgetary outlays, that amounted to about 1.4 percent of GDP, were mandated by the Presidency and consisted mainly of purchases of vehicles and public works. They were financed by the issuance of securities payable over three years.
} 
spending. This deficit was largely covered by central bank financing and arrears accumulation.

8. Monetary policy remained accommodative of the expansionary fiscal stance. The financing of the fiscal deficit through central bank advances resulted in continued rapid growth of both reserve and broad money, despite an increased use of central bank sterilization bills to control liquidity. This contributed to the inflationary pressures ${ }^{3}$ and the hoarding of foreign exchange, despite some increases in interest rates. ${ }^{4}$ In the absence of external budgetary assistance, net foreign assets of the central bank remained negative. In the area of banking supervision, banks remained generally sound (Table 4), with adequate provisioning of non-performing loans and a waitand-see attitude of managers in an uncertain environment. However, risk concentration remains a concern as all banks but two have excessive exposure to a few clients. One bank remains undercapitalized, but is otherwise profitable.

9. The authorities continued to operate a dual exchange market in 2004. The official market continued to be limited to the financing of government outlays and a few selected imports (mainly petroleum and rice), and the parallel market remained the default market for most exchange transactions. After a devaluation of about 27 percent in July, the official rate remained fixed for the remainder of 2004. It was further depreciated by a little over 10 percent in early 2005. The spread between the official and parallel rates averaged around 30 percent for most of the year. The Guinean franc depreciated by 5.7 percent in 2004 in real effective terms.

${ }^{3}$ The monetary pass-through to inflation is estimated at around 33 percent in Guinea, with a six-month lag (Country Report No. 03/251).

${ }^{4}$ On July 1 , the central bank raised the minimum rate on term deposits from 6.5 percent to 8.4 percent per annum, and introduced a minimum rate of 11.2 percent on saving accounts under GNF 20 million. Given possible negative medium-term effects on financial intermediation, the authorities intend to reverse this increase as monetary conditions permit. 


\section{There was little progress on} structural reforms. The new banking law was adopted by the government and submitted to parliament. A number of regulated prices were adjusted to reflect movements in international prices and exchange rate developments. However, no major steps were taken to restructure public utility enterprises and there were further delays in the finalization of the microfinance law. The authorities organized a national workshop on the Extractive Industries Transparency Initiative in late April 2005, in preparation for Guinea's future adherence to that Initiative.

\section{During the first quarter of 2005, the authorities implemented the agreed} minimum requirements for the negotiation of a SMP. A tight budget for 2005 was adopted by the National Assembly on March 24. On March 1, the authorities began the process of unifying the foreign exchange system by abandoning the artificial official foreign exchange auction. ${ }^{5}$ The official exchange rate is now determined by a reference rate taken from rates quoted by commercial banks and the Central Bank does not intervene in the market. ${ }^{6}$ The move to the new exchange rate regime has been welcomed by commercial banks. Regarding the safeguards assessment measures, an audit committee for the central bank was established in early February and the terms of reference for the special audit of the foreign reserves of the central bank and the audit of the central bank itself were finalized at end-March. ${ }^{7}$

\section{Fiscal policy was tightened in the first quarter of 2005, but monetary expansion} remained significant. The fiscal revenue target was achieved and expenditure commitments remained at a low level in the absence of a budget for 2005. As a result, there was a near overall balance on a commitment basis. On a cash basis, the deficit was equivalent to 0.4 percent of GDP because of the payment of 2004 commitments. Monetary expansion was significantly higher than anticipated due to unsterilized purchases of gold by the central

\footnotetext{
${ }^{5}$ A Fund technical expert visited Conakry during March 12-23 to help the Central Bank with the early transitional phase of the change.

${ }^{6}$ The Central Bank is studying the recommendations of MFD technical assistance to define its strategies for future official intervention in the exchange market.

${ }^{7}$ The staff's comments on the terms of reference for these two audits were incorporated. The bids for these audits were launched in early April.
} 
bank $^{8}$ and the impact of the exchange rate depreciation on foreign exchange balances. ${ }^{9}$ Yearon-year expansion of broad money was 44.2 percent at end-March 2005 compared with 37 percent at end-December 2004.

13. Guinea continued to face difficulties in servicing its external debt. Total external arrears to multilateral and bilateral creditors accumulated at end-2004 amounted to US\$62.4 million (about 2 percent of GDP). There were a large number of incidences of arrears to the Fund. ${ }^{10}$ Guinea accumulated a further US\$13.8 million in arrears during the first quarter of 2005, notably to the African Development Bank and the European Investment Bank, mostly due to the scarcity of foreign exchange. It has remained, however, current on its obligations to the Fund since late March 2005.

14. On May 14, 2005, the government increased petroleum pump prices by about 55 percent, bringing prices to above market level in an effort to recoup earlier financial losses and forestall further price adjustments. Retail petroleum prices had remained unchanged since mid-August 2004. The government announced at the same time an average increase of 2.4 percent in salaries and a doubling of the transport premium for civil servants.

\section{Policy Discussions}

\section{The overriding goal for the staff-monitored program is to tighten fiscal and} monetary policies in order to restore macroeconomic stability. Macroeconomic objectives for 2005 are to reach a real GDP growth of 3 percent, predicated on a rebound in the mining sector ${ }^{11}$ and trade and services picking up as the macroeconomic situation stabilizes, reduce the year-end consumer price inflation from 27.6 percent at end-2004 to below 19 percent, and increase gross reserves from 1.2 to 1.5 months of imports. These objectives were set in light of recent macroeconomic developments, planned measures under

\footnotetext{
${ }^{8}$ The Central Bank purchased the domestically mined gold to boost its reserves in order to settle external debt service. This contributed to about one fifth of the expansion in base money during the first quarter of 2005.

${ }^{9}$ Foreign currency deposits represented about 40 percent of total deposits at end-March 2005. The liberalization of the exchange market on March 1 resulted in a de facto depreciation of the official rate by about 16 percent.
}

${ }^{10}$ Since January 2004, Guinea has incurred short-term arrears to the Fund on 38 occasionswith settlement often occurring only two or three weeks after the due date. In particular, Guinea had been in continuous arrears to the PRGF Trust from late November 2004, which peaked at SDR 4.7 million in early February 2005. Since then, Guinea has made several payments and since late March 2005 has no arrears to the Fund.

${ }^{11}$ The rebound in the mining sector is attributed to a continued increase in private investment in the sector. 
the new program, and the recommendations of the 2004 Ex-Post Assessment for Guinea not to be overambitious in setting program targets. The program also includes structural reforms targeted to support macro-stabilization efforts, notably rekindling the privatization program and restructuring of the water and electricity distribution companies, and lay the basis for stronger and sustained economic growth.

\section{Discussions focused on required measures in the fiscal and monetary areas to} reach the program's macroeconomic objectives for 2005. In view of the stronger-thanexpected monetary expansion during the first quarter of this year, the staff concurred with the authorities that the scale of the fiscal adjustment that would be needed to achieve the monetary and inflation targets underlying the 2005 budget would be too contractionary. The authorities agreed with the staff's recommendation to extend the duration of the SMP through March 2006. They requested, however, that discussions of a PRGF-supported program be initiated earlier than the allocated twelve months, if program's objectives (defined in the quantitative macro framework and concerning largely fiscal and monetary targets) were attained earlier than the 12 months time frame.

\section{A. Fiscal Policies}

17. The authorities agreed that the implementation of a sound fiscal policy was critical to achieving the objectives of the SMP. The domestic fiscal adjustment underlying the program consists of an increase of 1.7 percent of GDP in revenue and a curtailment in primary current expenditure by 1.5 percent of GDP. The scale of fiscal adjustment is driven by lack of external financing, limiting domestic bank financing to program levels, and avoiding any further accumulation of domestic and external arrears. The primary surplus is targeted at 3 percent of GDP and the overall deficit (commitment basis, excluding grants) at 1.7 percent of GDP, down from 5.9 percent in 2004. Regarding the financing of the deficit, the authorities intend to give preference to auctions of treasury bills over direct financing by central bank, as indicated in the MEFP (paragraph 19). They have also opted for negative domestic non-bank financing in order to gradually eliminate government domestic debt. The financing gap, which is equivalent to US\$8.2 million ( 0.3 percent of GDP) is expected to be covered by assistance from development partners.

18. The increase in revenue is predicated on an uplift in mining revenue and a wide ranging set of tax administration measures set out in the MEFP (paragraph 16). The projected increase in mining revenue reflects the impact of new investments and better enforcement of the mining contracts. The measures include the application of the common external tariff of the West African Economic and Monetary Union (WAEMU) that was adopted as part of Guinea's membership of the Economic Community of West African States (ECOWAS) during the first quarter of this year (expected yield in 2005 of 0.4 percent of 
GDP), ${ }^{12}$ and the elimination of ad hoc tax exemptions, combating tax evasion, and strengthening customs administration, in accordance with the recommendations of the December 2004 FAD technical assistance mission in customs administration. By end-June 2005, the authorities plan to start implementing an action plan for strengthening tax and customs administrations, based on the recommendations of past IMF technical assistance missions.

19. The authorities and the mission agreed that strict implementation of the $\mathbf{2 0 0 5}$ budget would be key to the success of the program. The 2005 budget reflects the government's determination to contain nonpriority expenditure, particularly transfers to the defense sector and spending related to missions abroad. Total government expenditure in 2005 was set at 13.8 percent, which is 2.7 percentage points below the 2004 level. Budget allocations for spending directly related to poverty reduction have been increased from 3.0 percent of GDP in 2004 to 3.6 percent of GDP in 2005. The wage bill has been set at 2.9 percent of GDP, slightly below its 2004 level of 3.1 percent. The budget also provides for payment of external debt service due in 2005 and of about one fifth of external arrears accumulated in 2004. Understandings were also reached with the authorities that they would implement further revenue-enhancing measures and expenditure cuts if needed to achieve program objectives, which would be reflected in future staff assessments.

20. Public expenditure management will be strengthened to improve the monitoring of budget execution, streamline budget procedures and enhance transparency (MEFP, paragraph 17). Actions will be taken to: (i) enforce the application of budget and accounting rules and procedures, specifically by prohibiting the issuance of securities to finance offbudget spending; ${ }^{13}$ (ii) close the loopholes that may allow government entities to exceed their budgetary allocations; (iii) make the computerized budget management system fully operational; (iv) unify existing personnel management systems; and (v) strengthen the capacity of government audit and control agencies. These actions are in line with the recommendations made by the February 2005 FAD technical assistance mission. Furthermore, the authorities will pursue efforts to improve expenditure composition, notably in preparing the 2006 budget.

21. The authorities intend to find a sustainable way of clearing domestic arrears. To this end, they are undertaking an inventory of domestic debt and cross debts between public enterprises and the government. In the meantime, measures are being implemented to

12 Members of ECOWAS have decided to harmonize their external tariff system with that of the WAEMU as a step to encourage regional trade and simplify existing national tariff systems.

${ }^{13}$ These would preclude the extrabudgetary spending mandated by the Presidency mentioned in paragraph 7 . 
expedite the settlement of invoices from public enterprises and to strengthen the control of the central government's use of services provided by public enterprises.

\section{B. Monetary and Exchange Rate Policies}

22. The authorities concurred with the staff that restrictive monetary policies would be critical to get inflation on a clear downward path and improve the foreign reserves position of the Central Bank. The stronger-than-expected monetary expansion during the first quarter of 2005 has heightened the need for a more proactive monetary policy. The program seeks to achieve a gradual decline in broad money, from a quarterly growth rate of 13.3 percent during the first quarter of 2005 to below 3.5 percent each quarter from April 2005 to March 2006, in order to limit the annual growth rate in broad money to 13.8 percent at end-March 2006. Growth in reserve money from April 2005 to March 2006 would be contained at 7.6 percent, by limiting recourse to central bank advances to the government and through greater interest rate flexibility. This stance would contain money supply growth to the agreed target, lower inflationary pressures and, in light of the observed stickiness of nominal interest rates, help maintain positive real rates of interest. The authorities' monetary program also seeks to reach a net reserves position of at least US\$35.5 million at end-March 2006 (about 1 percent of GDP), as an intermediate step toward achieving the gross reserves target of 2.8 in months of imports at end-2006 (compared to 1.5 at end-2005).

23. The authorities intend to strengthen the functioning of the foreign exchange market after its liberalization, in light of the recommendations of recent MFD technical assistance missions. The ultimate goal of the reform is to make the liberalized market work efficiently, increasing the use of the banking system and eventually eliminating the role of the parallel exchange market. To achieve this goal, the authorities plan to: (i) reinforce the supervisory authorities to regulate the foreign exchange market; (ii) increase information flows in the market; (iii) improve the market microstructure; and (iv) foster two-way risk in the market to help develop risk management expertise and minimize destabilizing trade strategies. The authorities were receptive to the mission's advice, but wish to receive for further assistance from MFD to implement planned measures aimed at strengthening the institutional setup of the market. ${ }^{14}$

\footnotetext{
${ }^{14}$ MFD has not yet received an official request for technical assistance from the Guinean authorities. This issue will be discussed during the upcoming MFD need assessment mission scheduled for early June this year.
} 


\section{Box 1. Guinea: Implementation of the new exchange rate regime}

- In the new exchange rate regime adopted on March 1, 2005, the Central Bank withdrew from setting an official rate, and has been taking as a reference point the arithmetic average of rates quoted weekly by deposit banks. The foreign exchange market has been relatively calm since then. The reference rate has depreciated by about 20 percent, compared to the exchange rate from the last official auction. The spread between the rates quoted by foreign exchange bureaus and the average rates quoted by banks has stabilized at around 8 percent. Deposit banks have expressed satisfaction with the new foreign exchange regime.

- Staff believes that, by excluding the rates quoted by the exchange bureaus in the calculation of the reference rate, the multiple currency practice has not been completely eliminated. To remedy this, the Central Bank has started since May 25, 2005 to calculate the reference rate as a weighted average of rates quoted by deposit banks and foreign exchange bureaus. While the upcoming Article IV consultation will examine this in detail, it is expected that any remaining exchange rate restriction and multiple currency practice will have been eliminated. The Central Bank also plans to publish the reference rate daily, from the present weekly setting, in the near future.

- The Central Bank's priority is to ensure a proper functioning of the foreign exchange market. To this end, it is taking steps to reduce delays in transferring foreign exchange deposited by banks to their foreign correspondents. The Central Bank also intends to strengthen the existing mechanisms for the supervision of the market and to review regulations governing foreign exchange operations. Actions are already being taken to enforce rigorously the ban on foreign exchange trading in unauthorized locations and to restrict the trading to banks and authorized bureaus.

\section{The Central Bank will pursue implementation of the safeguards assessment} measures in order to strengthen its financial statements and bring them into line with international standards for bank accounting. Specifically, the special audit of the foreign assets of the central bank will be completed by end-September 2005 and the financial audit of the central bank itself by end-December. Furthermore, all accounts held by individuals on the books of the central bank will be closed by end-2005. Also, the government is committed to step up the implementation of measures to combat money laundering and the financing of terrorism, particularly in terms of customer identification.

\section{While Guinea's banking sector appears relatively sound, the staff stressed the} need for further efforts to enforce supervisory rules. The authorities indicated that one bank in distress will be recapitalized by end-December 2005 and that prompt actions are being taken to step up the supervision of the sector, in line with technical assistance provided by MFD. These supervision efforts are being extended to microfinance institutions subject to the new rules set out in various BCRG instructions. The authorities will also ensure prompt submission of the draft microfinance law to the National Assembly, so that it may be adopted along with the draft banking law, while pursuing the harmonization of microfinance institutions' accounting systems. 


\section{External Sector Policies and Debt}

26. The external current account is expected to improve in 2005 to 2.9 percent of GDP from 4.3 percent in 2004 due to an increase in the volume and prices of bauxite exports. ${ }^{15}$ The overall balance of payments deficit is projected at about 0.1 percent of GDP, with a residual financing gap of US\$ 8.2 million, which is expected to be covered by external grants, notably from the EU. Gross reserves would increase from 1.2 to 1.5 months of imports at end-2005. The adoption by Guinea of the WAEMU's common external tariff and the removal of non-tariff barriers have resulted in a more open trade regime. The extent and impact of these changes will be examined in more detail during the 2005 Article IV consultations. The authorities indicated that they would pursue efforts to promote export diversification, while maintaining a liberal trade system. To this end, they intend to strengthen the implementation of measures recommended by the 2003 Diagnostic Trade Integration Study (DTIS) to reduce supply constraints. They are also actively participating in regional trade integration initiatives, notably in the context of ECOWAS, aimed at improving trade-related institutions and infrastructure in the region.

27. The 2005 budget provides for the payment of all current debt obligations and the settlement of US\$8.4 million (0.2 percent of GDP) of external arrears, notably to multilateral creditors and on post-cutoff Paris Club debt. The authorities will continue, in parallel, to seek a rescheduling of existing debt as an interim step to a comprehensive solution under the enhanced HIPC Initiative. ${ }^{16}$ The staff stressed that timely settlement of forthcoming obligations to the Fund under the SMP will constitute an important element of the authorities' cooperation with the Fund. ${ }^{17}$

\section{Other Structural Reforms and Governance}

28. Structural measures under the SMP aim at supporting macro-stabilization efforts and creating an environment more conducive to sustainable growth. The authorities consider that the key priority is the restructuring of the electricity, water, and telecommunications companies, in order to improve the availability and quality of service. In

${ }^{15}$ These projections take into account the March 2005 WEO projections for oil prices.

${ }^{16}$ Guinea has obtained informal agreement on debt service forbearance with selected Paris Club members and has reached rescheduling agreements with the Arab Bank for Economic Development in Africa and with the Saudi Fund for Development. The last debt sustainability analysis (see Country Report No. 04/392) found that since Guinea reached the decision point in 2000, its external debt indicators have deteriorated, owing mainly to lowerthan-projected exports. In particular, the NPV of debt-to-exports at end-2003 was 201.4 percent, compared with 166 percent projected for the same year at the decision point.

${ }^{17}$ The authorities agreed to explore the possibility of accumulating sufficient balances in Guinea's SDR account to ensure timely payment of its future obligations to the Fund. 
the water and electricity sectors, their immediate objectives are to improve the capacity utilization of existing infrastructure and to restore the financial situation of the electric utility. In the telecommunications sector, they aim at updating the regulatory framework to stimulate private investment in the sector. The World Bank is assisting the authorities in these areas.

29. The government intends to resume the divestiture program to enable the private sector to participate more fully in the economic and social development of the country. The 2005 program includes the sale of the government's shares in seven companies and assets in three enterprises (MEFP, paragraph 26). The expected financial impact of this program (about 0.1 percent of GDP) has been taken into account in the 2005 budget. The authorities have started preparing, in parallel, the privatization of some twenty enterprises over the next three years.

30. The authorities also intend to step up efforts to strengthen governance and the justice system, as outlined in the MEFP (paragraphs 27-28). In particular, they will use the results of the recent survey on corruption and governance to update the action plan of the National Agency to Combat Corruption (ANLC). This action plan, which will be adopted by end-September 2005, will include concrete objectives and performance indicators, as well as specific actions to improve governance in key public sectors. The authorities indicated their determination to accelerate the preparation of an anti-corruption law and pursue vigorously all cases of corruption. To this end, the recently-created Office for Complaints about Corruption will collect all cases brought to its attention and transmit them to the Ministry of Justice. The mission reiterated the need to confer to the ANLC an independent status so that it can efficiently play its role. Regarding the reform of the justice system, the authorities will implement the five decrees on the organization of the system that were signed in March 2005.

\section{E. Poverty Reduction Strategy}

31. The authorities intend to complete the second PRSP progress report by endJune 2005. This second report will present an update of the medium-term macroeconomic framework and will reflect the results of the recent household survey, the core welfare indicators questionnaire, the public expenditure tracking survey, the study of the integrated framework for trade, and other ad hoc surveys. The results will enable the authorities to identify more precisely the causes of poverty in Guinea and to refine the poverty reduction strategy. The authorities, with the assistance of donors, completed a second progress report on achieving the MDGs in February 2005. They intend to implement, beginning in 2006, an action plan to alleviate the key obstacles to achieving the MDGs, particularly in areas where significant challenges remain.

32. In line with the goals of the poverty reduction strategy, a 5 percent per year real GDP growth rate is targeted over the medium term. Achieving such a target is predicated on the implementation of measures geared towards unlocking the country's growth potential on three fronts: (i) enhancements in the regulatory environment, the financial system, and the rule of law, which would improve the climate for private investment; (ii) strengthening of the 
country's infrastructure (transport, energy, and telecommunications); and (iii) diversification of the economy's export structure.

\section{F. Program Risks and Monitoring}

33. Despite the authorities' stated commitment to macroeconomic stability, considerable risks remain. The uncertainty of the political situation may weaken the position of reformists in the government. In addition, the fragile security situation at borders may provide a pretext for increased defense spending. On the policy side, the authorities may not be able to break with past practices of extra budgetary spending and capacity constraint could limit the ability of the Central Bank to closely monitor monetary developments and conduct a more proactive monetary policy to control inflation.

34. The program will be monitored quarterly through quantitative indicative targets and structural benchmarks specified in Tables 1-2 of the MEFP. Indicative targets are defined and explained in the technical memorandum of understanding (TMU, Appendix I, Annex II). These targets aim to ensure that the program could achieve its main objectives of macroeconomic stability and lay the basis for higher and sustainable growth, improved social indicators, and medium term external sustainability. Structural benchmarks cover the areas of tax administration, expenditure control, safeguards, governance, and exchange rate regime. The SMP staff assessment testing end-June 2005 performance will incorporate directors' views that might arise during the Article IV consultation discussions.

\section{STAFF APPRAisal}

35. While policy implementation was very weak in 2004, there has been a substantial improvement in implementation since the nomination of the new Prime Minister in December 2004. The government's expansionary fiscal stance during 2004 accommodated by a loose monetary policy, its use of multiple exchange rates, and the absence of progress on structural reforms, resulted in poor economic performance, characterized by weak economic growth, accelerating inflation, and accumulation of domestic and external arrears. With the support of the President, the new Prime Minister has adopted a credible policy stance, pushing for the tightening of the fiscal and monetary policies to restore macroeconomic stability, and the adoption of key structural reforms to put the economy on the right footing for stronger medium-term growth. Nevertheless, improvement in the economic situation could be hampered by the fragile security situation at borders and continued internal political tensions. Government's economic policy credibility will only be restored by sustained policy implementation.

36. A key challenge for the authorities is to improve fiscal performance and management. The 2005 budget reflects the government's determination to improve revenue collection, control expenditure while allocating an increased share to priority sectors, and keep the use of bank financing in line with prudent monetary management. The proposed scale of adjustment, necessitated by financing constraints, is ambitious. Thus, maintaining 
fiscal discipline to abide with the 2005 budget will be essential to achieve the program objectives.

37. Raising revenue collection will be crucial for improving fiscal performance. The authorities have already taken a series of measures, including the reduction of tax exemptions and the adoption of WAEMU's common external tariff. The litmus test will be the will to tackle the implementation problems. The achievement of the revenue targets will also require a revamping of the tax and customs administrations, through the implementation of actions plans based on the recommendations of past IMF technical assistance missions.

38. The staff welcomes the efforts now underway to strengthen expenditure management. These efforts will improve the monitoring of budget execution, streamline budget procedures and enhance transparency. The staff considers it essential to strictly enforce budget rules and procedures, specifically by prohibiting extra budgetary expenditure. At the same time, the authorities are encouraged to pursue efforts to improve the functioning and comprehensiveness of the computerized expenditure management system.

39. A more proactive implementation of the monetary policy is essential to avert the risk of continued high inflation. The staff encourages the Central Bank to focus its monetary policy on controlling the growth of base money. To this end, liquidity management needs to be improved, based on the recommendations of MFD technical assistance missions, and central bank credit to the government strictly contained. The Central Bank should also continue to strengthen bank supervision and push for the adoption of the revised banking and microfinance laws by Parliament.

40. Planned measures to ensure a smooth and transparent functioning of the liberalized exchange market need to be implemented. These measures would improve the efficiency of the market and allow commercial banks to regain a central role in foreign exchange operations. Further technical assistance to the Central Bank would be needed to help it strengthen the institutional setup of the market.

41. The staff welcomes the structural reform agenda. The restructuring of the public utility companies should improve the availability and quality of service and raise factor productivity. The planned privatizations will diminish rent-seeking opportunities. The reform of the judiciary and the strengthening of the anti-corruption agency are essential to foster private sector development. The authorities are strongly encouraged to adhere to the Extractive Industries Transparency Initiative.

42. The risks to successful program implementation are significant. These risks include internal political tensions, the fragile security situation at borders, and institutional and capacity constraints. Planned quarterly staff assessments and further technical assistance may help reduce the impact of some of these risks.

\section{The authorities' program is designed to turn around a very difficult situation.}

The staff will closely monitor program implementation. This program will help the authorities establish a track record that can restore credibility in macroeconomic policy 
implementation and provide a basis for moving to a PRGF supported arrangement in due course. The staff supports the authorities' request that negotiations of a PRGF-supported program be initiated earlier than the allocated 12 months if program objectives are attained more rapidly than expected. 
Table 1. Guinea: Selected Economic and Financial Indicators, 2002-07

\begin{tabular}{|c|c|c|c|c|c|c|}
\hline & 2002 & 2003 & 2004 & 2005 & 2006 & 2007 \\
\hline & & & Est. & \multicolumn{2}{|c|}{ Proj. } & \\
\hline & \multicolumn{5}{|c|}{ (Annual percentage change, unless otherwise indicated) } & \\
\hline Income & & & & & & \\
\hline GDP at constant prices & 4.2 & 1.2 & 2.7 & 3.0 & 4.9 & 5.4 \\
\hline GDP at current prices & 7.1 & 13.7 & 23.2 & 24.8 & 16.8 & 11.5 \\
\hline GDP deflator & 2.8 & 12.3 & 19.9 & 21.3 & 11.3 & 5.7 \\
\hline \multicolumn{7}{|l|}{ Consumer prices } \\
\hline Average & 3.0 & 12.9 & 17.5 & 25.8 & 11.7 & 4.9 \\
\hline End of period & 6.1 & 14.8 & 27.6 & 18.6 & 6.2 & 4.0 \\
\hline \multicolumn{7}{|l|}{ External sector } \\
\hline Exports, f.o.b. (in U.S. dollar terms) & -2.0 & 2.5 & 0.9 & 5.6 & 9.3 & 9.3 \\
\hline Imports, f.o.b. (in U.S. dollar terms) & 6.1 & -3.0 & -1.5 & 1.3 & 12.3 & 8.8 \\
\hline \multicolumn{7}{|l|}{ Terms of trade } \\
\hline Percentage change & 2.4 & -2.2 & -11.0 & -3.4 & 1.3 & 5.8 \\
\hline \multicolumn{7}{|l|}{ Average effective exchange rates (depreciation -) } \\
\hline Nominal index & -3.3 & -11.7 & -17.3 & $\ldots$ & $\ldots$ & $\ldots$ \\
\hline Real index & -2.3 & -4.3 & -5.7 & $\ldots$ & $\ldots$ & $\ldots$ \\
\hline \multicolumn{7}{|l|}{ Money and credit } \\
\hline Net foreign assets $1 /$ & -11.9 & -9.4 & 11.4 & 7.0 & $\ldots$ & $\ldots$ \\
\hline Net domestic assets $1 /$ & 31.2 & 44.7 & 25.6 & 18.0 & $\ldots$ & $\ldots$ \\
\hline Net claims on government ( net) $1 /$ & 34.2 & 34.0 & 22.2 & 12.1 & $\ldots$ & $\ldots$ \\
\hline Credit to nongovernment sector $1 /$ & 3.5 & 7.8 & 2.3 & 8.1 & $\ldots$ & $\ldots$ \\
\hline Broad money & 19.2 & 35.3 & 37.0 & 25.0 & $\ldots$ & $\ldots$ \\
\hline Reserve money & 18.3 & 27.4 & 33.0 & 25.7 & $\ldots$ & $\ldots$ \\
\hline Treasury bill rate (end-of-period) & 13.3 & 14.1 & 14.7 & $\ldots$ & $\ldots$ & $\ldots$ \\
\hline Velocity (GDP/average 2 year-end M2) & 8.6 & 7.7 & 6.9 & 6.6 & $\ldots$ & $\ldots$ \\
\hline \multicolumn{7}{|c|}{ (In percent of GDP) } \\
\hline \multicolumn{7}{|l|}{ Central government finances } \\
\hline Total revenue and grants & 13.8 & 13.2 & 11.6 & 13.3 & 13.7 & 14.1 \\
\hline Of which: nonmining revenue & 9.8 & 9.0 & 8.6 & 9.0 & 9.2 & 9.6 \\
\hline Current expenditure & 12.2 & 12.9 & 11.4 & 9.7 & 9.4 & 9.6 \\
\hline Capital expenditure and net lending 2 / & 6.0 & 6.3 & 5.0 & 4.1 & 4.5 & 4.6 \\
\hline \multicolumn{7}{|l|}{ Overall budget balance } \\
\hline Including grants (commitment) & -4.4 & -6.0 & -4.9 & -0.5 & -0.2 & 0.0 \\
\hline Excluding grants (commitment) & -6.2 & -8.8 & -5.9 & -1.7 & -1.5 & -1.2 \\
\hline Primary balance & 0.0 & -2.5 & -0.5 & 3.0 & 3.3 & 3.4 \\
\hline Gross investment & 13.1 & 9.9 & 11.3 & 11.0 & 13.0 & 13.4 \\
\hline Government & 4.0 & 4.4 & 4.0 & 3.2 & 3.5 & 3.6 \\
\hline Nongovernment & 9.1 & 5.5 & 7.3 & 7.9 & 9.5 & 9.8 \\
\hline Domestic savings & 9.1 & 7.4 & 8.9 & 9.8 & 11.7 & 12.3 \\
\hline Government & 1.5 & -0.3 & 1.6 & 4.7 & 5.1 & 5.3 \\
\hline Nongovernment & 7.7 & 7.7 & 7.3 & 5.1 & 6.7 & 7.0 \\
\hline \multicolumn{7}{|l|}{ External current account balance } \\
\hline Including official transfers & -4.3 & -3.2 & -3.7 & -2.0 & -1.8 & -1.6 \\
\hline Excluding official transfers & -5.6 & -4.0 & -4.2 & -2.9 & -2.7 & -2.5 \\
\hline \multirow[t]{2}{*}{ Overall balance of payments } & -2.6 & -2.6 & -2.5 & -0.1 & 1.1 & 0.5 \\
\hline & \multicolumn{6}{|c|}{ (In percent of exports of goods and nonfactor services) } \\
\hline External public debt & 387.9 & 419.8 & 400.5 & 354.2 & 309.2 & 271.1 \\
\hline Memorandum items: & \multicolumn{6}{|c|}{ (In millions of U.S. dollars, unless otherwise indicated) } \\
\hline Exports f.o.b. & 708.5 & 726.5 & 733.0 & 774.3 & 846.6 & 925.3 \\
\hline Imports f.o.b. & 596.2 & 578.1 & 569.2 & 576.6 & 647.4 & 704.4 \\
\hline External current account (including official transfers) & -136.8 & -117.2 & -145.9 & -71.7 & -68.3 & -65.5 \\
\hline Overall balance of payments & -83.7 & -93.7 & -99.3 & -5.0 & 39.2 & 18.6 \\
\hline Net foreign assets(central bank) & 26.4 & -10.2 & -6.0 & 28.6 & 135.9 & 221.6 \\
\hline Gross official reserves (in months of imports) & 2.3 & 1.6 & 1.2 & 1.5 & 2.8 & 3.5 \\
\hline Gross reserves (in percent of broad money) & 41.9 & 25.2 & 19.9 & 23.5 & & \\
\hline Nominal GDP (in billions of Guinean francs) & 6,340 & 7,210 & 8,883 & 11,089 & 12,949 & 14,434 \\
\hline
\end{tabular}

Sources: Guinean authorities; and staff estimates and projections.

1 / In percent of broad money stock at beginning of period.

2 / Includes expenditure for restructuring. 
Table 2. Guinea: Financial Operations of the Government, 2002-07

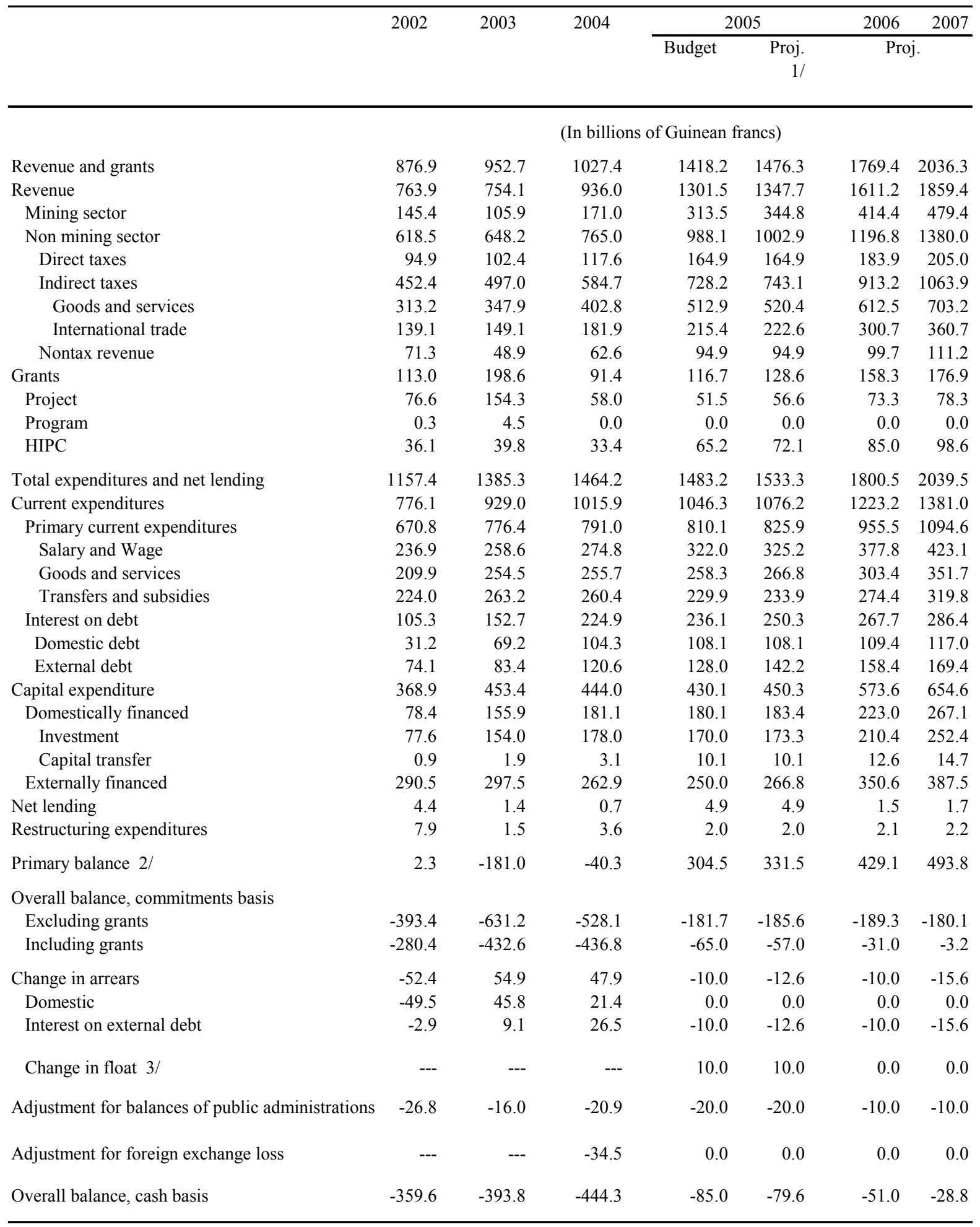


Table 2. Guinea: Financial Operations of the Government, 2002-07 (concluded)

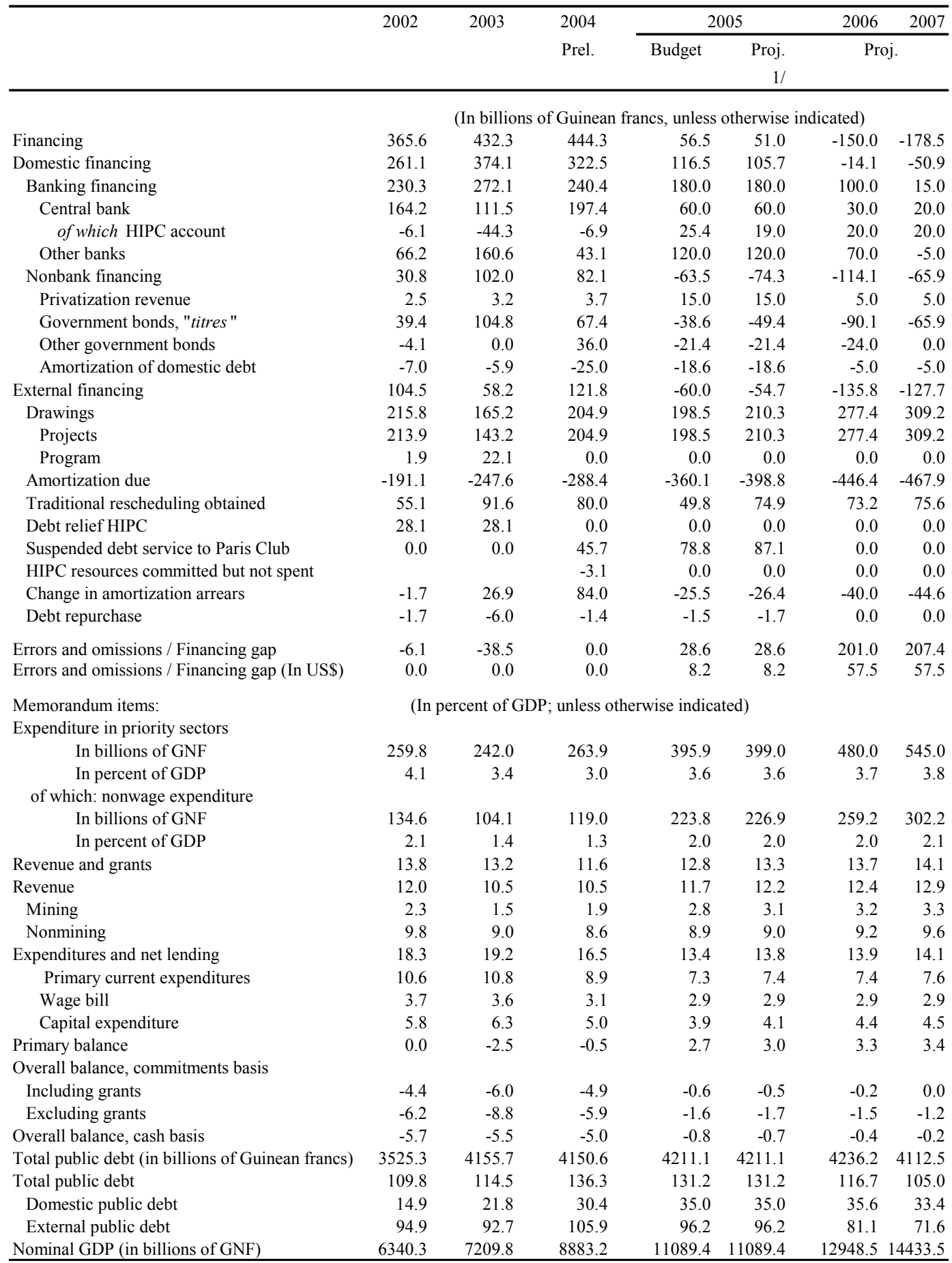

Sources: Guinean authorities; and staff estimates and projections.

1/ These projections take into account the new projected average annual exchange rate of 3150 GNF/US\$.

The 2005 budget was based on a projected average annual exchange of $2861.5 \mathrm{GNF} / \mathrm{US} \$$.

2/ Revenue minus noninterest expenditure, excluding foreign-financed investment projects.

$3 /$ This item comprises changes in expenditure commitments unpaid during a period of no more than 90 days beyond which they become arrears. For past year-end data, the change in float is consolidated with the change in domestic arrears. 
Table 3. Guinea: Monetary Survey, 2003-06

\begin{tabular}{|c|c|c|c|c|c|c|c|}
\hline & \multirow[t]{3}{*}{2003} & \multirow[t]{3}{*}{2004} & \multicolumn{4}{|c|}{2005} & \multirow{3}{*}{$\begin{array}{r}200 \\
\text { Marcl } \\
\text { Proj }\end{array}$} \\
\hline & & & \multirow{2}{*}{$\begin{array}{l}\text { March } \\
\text { Prel. }\end{array}$} & June & Sept. & Dec. & \\
\hline & & & & \multicolumn{3}{|c|}{ Proj. } & \\
\hline & \multicolumn{6}{|c|}{ (In billions of Guinean francs, unless otherwise indicated) } & \\
\hline \multicolumn{8}{|l|}{ Central bank } \\
\hline Net foreign assets & -20.5 & -15.2 & 2.2 & 30.1 & 59.1 & 100.1 & 124.1 \\
\hline (in millions of U.S. dollars) & -10.4 & -6.0 & 0.7 & 9.4 & 18.1 & 30.0 & 35.5 \\
\hline Net domestic assets & 594.4 & 778.5 & 905.3 & 896.1 & 883.4 & 859.5 & 852.8 \\
\hline Domestic credit & 529.0 & 677.2 & 727.1 & 747.1 & 742.8 & 728.8 & 724.3 \\
\hline Government, net & 525.7 & 723.1 & 750.0 & 780.4 & 783.3 & 783.1 & 790.0 \\
\hline Of which: gold revaluation claims & 55.4 & 55.4 & 55.4 & 55.4 & 55.4 & 55.4 & 55.4 \\
\hline Public enterprises & 2.7 & 2.7 & 2.7 & 2.7 & 2.7 & 2.7 & 2.7 \\
\hline Private sector & 33.5 & 31.9 & 33.9 & 33.9 & 33.9 & 33.9 & 34.5 \\
\hline Liabilities to deposit money banks (-) & -32.9 & -80.5 & -59.5 & -69.9 & -77.1 & -90.9 & -102.9 \\
\hline Of which: sterilization bills (-) & -34.5 & -82.5 & -67.0 & -72.0 & -79.2 & -92.9 & -105.0 \\
\hline Other items, net (assets + ) & 65.4 & 101.3 & 178.2 & 149.0 & 140.6 & 130.7 & 128.5 \\
\hline Reserve money & 573.9 & 763.3 & 907.5 & 926.2 & 942.5 & 959.6 & 976.9 \\
\hline Currency outside banks & 478.1 & 604.1 & 656.3 & 678.5 & 701.2 & 723.7 & 746.4 \\
\hline Bank reserves & 93.1 & 154.1 & 252.8 & 246.6 & 240.9 & 235.8 & 230.5 \\
\hline Deposits & 77.4 & 125.5 & 217.2 & 212.3 & 209.5 & 207.3 & 205.5 \\
\hline Required reserves & 33.3 & 48.4 & 56.4 & 58.4 & 60.3 & 62.3 & 64.2 \\
\hline Excess reserves & 44.1 & 77.1 & 160.8 & 153.9 & 149.2 & 145.0 & 141.3 \\
\hline Cash in till & 15.8 & 28.6 & 35.6 & 34.3 & 31.4 & 28.6 & 25.0 \\
\hline Private sector deposits & 2.7 & 5.1 & -1.6 & 1.1 & 0.5 & 0.0 & 0.0 \\
\hline \multicolumn{8}{|l|}{ Deposit money banks } \\
\hline Net foreign assets & 66.8 & 185.0 & 199.3 & 190.5 & 181.8 & 173.1 & 164.3 \\
\hline Bank reserves & 93.1 & 154.1 & 252.8 & 246.6 & 240.9 & 235.8 & 230.5 \\
\hline Deposits at the central bank & 77.4 & 125.5 & 217.2 & 212.3 & 209.5 & 207.3 & 205.5 \\
\hline Cash in till & 15.8 & 28.6 & 35.6 & 34.3 & 31.4 & 28.6 & 25.0 \\
\hline Claims on central bank & 32.9 & 80.5 & 59.5 & 69.9 & 77.1 & 90.9 & 102.9 \\
\hline Of which: sterilization bills & 34.5 & 82.5 & 67.0 & 72.0 & 79.2 & 92.9 & 105.0 \\
\hline Domestic credit & 606.2 & 672.1 & 772.1 & 830.1 & 888.1 & 910.6 & 972.0 \\
\hline Credit to the government & 245.4 & 288.5 & 311.9 & 354.9 & 397.9 & 408.5 & 451.9 \\
\hline Claims & 285.9 & 386.2 & 357.6 & 429.4 & 472.4 & 483.0 & 526.4 \\
\hline Deposits & 40.5 & 97.7 & 45.7 & 74.5 & 74.5 & 74.5 & 74.5 \\
\hline Claims on public enterprises & 3.9 & 0.0 & 0.0 & 0.0 & 0.0 & 0.0 & 0.0 \\
\hline Claims on the private sector & 356.9 & 383.6 & 460.2 & 475.2 & 490.1 & 502.1 & 520.1 \\
\hline Other items, net (assets + ) & -196.6 & -216.3 & -256.6 & -275.8 & -291.1 & -278.4 & -302.2 \\
\hline Liabilities to the private sector (deposits) & 602.5 & 875.4 & $1,027.1$ & $1,061.3$ & $1,096.7$ & $1,132.0$ & $1,167.5$ \\
\hline
\end{tabular}


Table 3. Guinea: Monetary Survey, 2003-06 (concluded)

\begin{tabular}{|c|c|c|c|c|c|c|}
\hline \multirow[t]{6}{*}{2003} & \multirow[t]{6}{*}{2004} & \multirow{2}{*}{\multicolumn{4}{|c|}{2005}} & \\
\hline & & & & & & \\
\hline & & & \multirow{2}{*}{\multicolumn{3}{|c|}{ Proj. }} & \\
\hline & & & & & & 2006 \\
\hline & & March & June & Sept. & Dec. & March \\
\hline & & Prel. & & & & Proj. \\
\hline
\end{tabular}

(In billions of Guinean francs, unless otherwise indicated)

\begin{tabular}{|c|c|c|c|c|c|c|c|}
\hline \multicolumn{8}{|l|}{ Monetary survey } \\
\hline Net foreign assets & 46.3 & 169.8 & 201.5 & 220.6 & 240.9 & 273.2 & 288.4 \\
\hline Net domestic assets & $1,037.0$ & $1,314.8$ & $1,480.3$ & $1,519.2$ & $1,556.9$ & $1,582.6$ & $1,625.5$ \\
\hline Domestic credit & $1,168.2$ & $1,429.8$ & $1,558.7$ & $1,647.1$ & $1,708.0$ & $1,730.3$ & $1,799.2$ \\
\hline Credit to the government & 771.2 & $1,011.6$ & $1,061.9$ & $1,135.4$ & $1,181.3$ & $1,191.6$ & $1,241.9$ \\
\hline Claims on public enterprises & 6.6 & 2.7 & 2.7 & 2.7 & 2.7 & 2.7 & 2.7 \\
\hline Claims on the private sector & 390.4 & 415.5 & 494.2 & 509.1 & 524.0 & 536.0 & 554.6 \\
\hline Other items, net (assets + ) & -131.1 & -115.0 & -78.4 & -127.9 & -151.1 & -147.7 & -173.7 \\
\hline Broad money (M2) & $1,083.3$ & $1,484.6$ & $1,681.8$ & $1,739.9$ & $1,797.9$ & $1,855.7$ & $1,913.9$ \\
\hline Currency & 478.1 & 604.1 & 656.3 & 678.5 & 701.2 & 723.7 & 746.4 \\
\hline Deposits & 605.2 & 880.5 & $1,025.5$ & $1,061.3$ & $1,096.7$ & $1,132.0$ & $1,167.5$ \\
\hline Of which: foreign currency deposits & 157.9 & 271.0 & 405.3 & 389.2 & 373.2 & 359.2 & 341.0 \\
\hline Memorandum items: & \multicolumn{7}{|c|}{$\begin{array}{l}\text { (Year-on-year change in percent of beginning-of-period broad money, } \\
\text { unless otherwise indicated) }\end{array}$} \\
\hline Net foreign assets & -9.4 & 11.4 & 12.4 & 5.8 & 6.3 & 7.0 & 5.2 \\
\hline Net domestic assets & 44.7 & 25.6 & 31.8 & 26.3 & 19.3 & 18.0 & 8.6 \\
\hline Domestic credit & 41.8 & 24.1 & 29.0 & 29.9 & 24.1 & 20.2 & 14.3 \\
\hline Net claims on government & 34.0 & 22.2 & 19.0 & 19.4 & 16.1 & 12.1 & 10.7 \\
\hline Credit to nongovernment sector & 7.8 & 2.3 & 10.0 & 10.6 & 8.0 & 8.1 & 3.6 \\
\hline Broad money & 35.3 & 37.0 & 44.2 & 32.1 & 25.6 & 25.0 & 13.8 \\
\hline Velocity (GDP/average M2) & 7.7 & 6.9 & $\ldots$ & $\ldots$ & $\ldots$ & 6.6 & $\ldots$ \\
\hline $\begin{array}{l}\text { Commercial bank credit to the private sector } \\
\text { (annual percentage change) }\end{array}$ & 20.9 & 7.5 & 34.0 & 40.9 & 30.3 & 30.9 & 13.0 \\
\hline Reserve money (annual percentage change) & 27.4 & 33.0 & 48.1 & 44.8 & 32.6 & 25.7 & 7.6 \\
\hline Quarterly growth in broad money & $\ldots$ & $\ldots$ & 13.3 & 3.5 & 3.3 & 3.2 & 3.1 \\
\hline
\end{tabular}

Sources: Guinean authorities; and staff estimates and projections. 
Table 4. Guinea: Financial Soundness Indicators for the Banking System, 2000-04

\begin{tabular}{|c|c|c|c|c|c|c|}
\hline & Net capital & $\begin{array}{l}\text { Solvability } \\
\text { ratio } 2 /\end{array}$ & $\begin{array}{l}\text { Liquidity } \\
\text { ratio } 4 /\end{array}$ & $\begin{array}{l}\text { Concentration } \\
\text { of risk ratio } 5 /\end{array}$ & $\begin{array}{l}\text { Division of } \\
\text { risk 6/ }\end{array}$ & $\begin{array}{l}\text { NPL } \\
\text { ratio 7/ }\end{array}$ \\
\hline & GNF 5 billion $1 /$ & $8 \%(10 \%, 3 /)$ & $70 \%(100 \%, 3 /)$ & $\begin{array}{l}\text { Eight time } \\
\text { net capital }\end{array}$ & 0 & \\
\hline & Minimum & Minimum & Maximum & maximum & Maximum & \\
\hline & \multicolumn{5}{|c|}{ (In number of banks complying with the prudential ratios) } & In percent \\
\hline End-2000 & 4 & 3 & 7 & 4 & 1 & 25.0 \\
\hline End-2001 & 5 & 4 & 7 & 5 & 2 & 27.7 \\
\hline End-2002 & 5 & 7 & 7 & 7 & 3 & 25.7 \\
\hline End- 2003 & 6 & 7 & 7 & 7 & 5 & 28.0 \\
\hline End-2004 & 6 & 7 & 7 & 7 & 2 & 26.2 \\
\hline
\end{tabular}

1/ The minimum regulatory net capital was set at GNF 2 billion before March 2002

2/ Regulatory capital to risk-weighted assets

3/ Corresponds to the new prudential ratios, effective June 2003

4/ Liquid assets to short-term liabilities

$5 /$ Total of loans larger than 15 percent of net capital divided by net capital

6/ Number of loans larger than 25 percent of capital

$7 /$ Non-performing loans to total loans, before provisions. The provisioning rate of non-performing loans was $98 \%$ at end-2004. 
Table 5. Guinea: Balance of Payments, 2002-09

(In millions of U.S. dollars; unless otherwise indicated)

\begin{tabular}{|c|c|c|c|c|c|c|c|c|}
\hline & 2002 & 2003 & 2004 & 2005 & 2006 & 2007 & 2008 & 2009 \\
\hline & & & Prel. & & & Proj. & & \\
\hline Merchandise trade balance & 112.4 & 148.4 & 163.8 & 197.7 & 199.2 & 220.8 & 252.7 & 273.4 \\
\hline Exports, f.o.b. & 708.5 & 726.5 & 733.0 & 774.3 & 846.6 & 925.3 & $1,014.0$ & $1,098.9$ \\
\hline Of which: mining products & 619.9 & 624.8 & 629.4 & 658.4 & 725.9 & 795.2 & 873.6 & 947.5 \\
\hline Imports, f.o.b. & -596.2 & -578.1 & -569.2 & -576.6 & -647.4 & -704.4 & -761.3 & -825.5 \\
\hline Food products & -119.5 & -112.9 & -102.0 & -102.6 & -111.7 & -124.8 & -134.7 & -137.1 \\
\hline Other consumption goods & -97.0 & -102.1 & -90.0 & -82.8 & -99.6 & -100.0 & -101.3 & -105.2 \\
\hline Petroleum goods & -89.9 & -96.5 & -113.8 & -123.4 & -132.4 & -143.5 & -145.3 & -149.5 \\
\hline Intermediate and capital goods & -289.8 & -266.6 & -263.5 & -267.9 & -303.7 & -336.1 & -380.0 & -433.7 \\
\hline Services trade balance & -239.6 & -238.9 & -256.3 & -239.6 & -244.8 & -264.9 & -287.6 & -307.2 \\
\hline Services exports & 76.7 & 74.8 & 70.4 & 95.5 & 105.8 & 109.7 & 112.3 & 114.8 \\
\hline Of which: transport & 8.9 & 6.7 & 6.8 & 7.2 & 7.8 & 8.6 & 9.4 & 10.2 \\
\hline Services imports & -316.3 & -313.7 & -326.7 & -335.1 & -350.6 & -374.6 & -399.9 & -422.0 \\
\hline Of which: transport & -107.4 & -93.7 & -89.5 & -95.2 & -98.1 & -102.1 & -107.1 & -108.1 \\
\hline Income balance & -38.0 & -31.7 & -52.7 & -41.4 & -41.5 & -43.2 & -45.0 & -46.9 \\
\hline Of which: dividend payments & -1.2 & -0.8 & -1.7 & -1.3 & -1.4 & -1.4 & -1.5 & -1.6 \\
\hline interest on public debt $1 /$ & -37.5 & -42.0 & -53.2 & -45.1 & -45.3 & -46.9 & -48.5 & -50.1 \\
\hline Transfers & 28.4 & 5.1 & -0.8 & 11.7 & 18.7 & 21.8 & 20.3 & 17.6 \\
\hline Of which: net private transfers & -15.3 & -22.7 & -21.1 & -17.0 & -11.6 & -11.7 & -11.9 & -12.9 \\
\hline official transfers & 25.5 & 7.8 & 5.7 & 5.8 & 6.0 & 6.2 & 6.4 & 6.6 \\
\hline HIPC Initiative assistance (multilat.) & 18.3 & 20.0 & 14.7 & 22.9 & 24.3 & 27.3 & 25.8 & 23.9 \\
\hline \multicolumn{9}{|l|}{ Current account } \\
\hline Including official transfers & -136.8 & -117.2 & -145.9 & -71.7 & -68.3 & -65.5 & -59.6 & -63.1 \\
\hline Excluding official transfers & -180.5 & -145.0 & -166.3 & -100.4 & -98.6 & -99.0 & -91.8 & -93.6 \\
\hline Capital account & 38.8 & 77.7 & 25.6 & 18.0 & 21.0 & 21.7 & 22.4 & 23.2 \\
\hline Public transfers (project grants) & 38.8 & 77.7 & 25.6 & 18.0 & 21.0 & 21.7 & 22.4 & 23.2 \\
\hline Financial account & 43.7 & -22.8 & 0.5 & 48.7 & 86.6 & 62.4 & 65.9 & 72.6 \\
\hline Public (medium and long term) & 12.5 & -41.5 & -30.6 & -28.2 & -27.4 & -24.4 & 3.4 & 12.9 \\
\hline Project-related loans & 108.3 & 72.1 & 90.3 & 87.3 & 91.8 & 99.2 & 106.6 & 114.4 \\
\hline Program financing & 1.0 & 11.1 & 0.0 & 0.0 & 0.0 & 0.0 & 0.0 & 0.0 \\
\hline Amortization due $1 /$ & -96.8 & -124.7 & -120.9 & -115.5 & -119.2 & -123.6 & -103.2 & -101.5 \\
\hline Direct and other private investment (net) & 31.2 & 18.7 & 31.1 & 77.0 & 114.0 & 86.8 & 62.5 & 59.7 \\
\hline Errors and omissions & -29.3 & -31.4 & 20.6 & 0.0 & 0.0 & 0.0 & 0.0 & 0.0 \\
\hline Overall balance & -83.7 & -93.7 & -99.3 & -5.0 & 39.2 & 18.6 & 28.7 & 32.7 \\
\hline
\end{tabular}


Table 5. Guinea: Balance of Payments, 2002-09 (concluded)

(In millions of U.S. dollars; unless otherwise indicated)

\begin{tabular}{|c|c|c|c|c|c|c|c|c|}
\hline & \multirow[t]{2}{*}{2002} & \multirow[t]{2}{*}{2003} & \multirow{2}{*}{$\begin{array}{c}2004 \\
\text { Prel. }\end{array}$} & 2005 & 2006 & 2007 & 2008 & 2009 \\
\hline & & & & \multicolumn{5}{|c|}{ Proj. } \\
\hline Financing & 83.7 & 93.7 & 99.5 & -3.2 & -96.7 & -76.0 & -63.7 & -62.7 \\
\hline Change in net official reserves & 43.8 & 15.3 & -4.4 & -36.0 & -105.9 & -85.7 & -73.9 & -82.2 \\
\hline Of which: Net use of Fund resources & 5.4 & -16.4 & -22.5 & -21.9 & -20.2 & -21.5 & -18.2 & -12.8 \\
\hline Changes in arrears and government assets (net) & -2.3 & 18.1 & 48.9 & -12.4 & -11.7 & -11.3 & -10.8 & 0.0 \\
\hline Suspended debt service to Paris Club & 0.0 & 0.0 & 20.2 & 27.6 & 0.0 & 0.0 & 0.0 & 0.0 \\
\hline Debt relief & 42.1 & 60.3 & 34.8 & 17.6 & 20.9 & 21.0 & 21.0 & 19.5 \\
\hline Of which: HIPC Initiative assistance & 14.2 & 14.1 & 0.0 & 0.0 & 0.0 & 0.0 & 0.0 & 0.0 \\
\hline Residual financing gap & 0.0 & 0.0 & 0.0 & 8.2 & 57.5 & 57.5 & 35.0 & 30.0 \\
\hline \multicolumn{9}{|l|}{ Memorandum items: } \\
\hline \multicolumn{9}{|l|}{ Current account-GDP ratio (in percent) } \\
\hline Including official transfers & -4.3 & -3.2 & -3.7 & -2.0 & -1.8 & -1.6 & -1.4 & -1.4 \\
\hline Excluding official transfers & -5.6 & -4.0 & -4.2 & -2.9 & -2.7 & -2.5 & -2.1 & -2.0 \\
\hline Overall balance (in percent of GDP) & -2.6 & -2.6 & -2.5 & -0.1 & 1.1 & 0.5 & 0.7 & 0.7 \\
\hline Exports-GDP ratio (in percent) & 24.5 & 22.1 & 20.5 & 24.7 & 25.7 & 25.9 & 26.2 & 26.3 \\
\hline Imports-GDP ratio (in percent) & -28.4 & -24.6 & -22.9 & -25.9 & -26.9 & -27.0 & -27.0 & -27.0 \\
\hline External medium-and long-term public debt & 3,046 & 3,364 & 3,218 & 3,081 & 2,945 & 2,806 & 2,367 & 2,263 \\
\hline In percent of GDP & 94.9 & 92.7 & 105.9 & 96.2 & 81.1 & 71.6 & 67.2 & 61.1 \\
\hline Debt-service ratio 2/ & 9.0 & 12.5 & 11.4 & 10.7 & 10.0 & 9.6 & 6.5 & 5.3 \\
\hline NPV of external debt (in percent of exports) & 208.2 & 201.4 & 197.4 & 183.7 & 166.6 & 149.9 & --- & --- \\
\hline Gross reserves & 170.0 & 138.3 & 115.9 & 124.6 & 232.1 & 314.7 & 388.7 & 467.8 \\
\hline In months of imports of the following year & 2.3 & 1.6 & 1.2 & 1.5 & 2.8 & 3.5 & 4.0 & 4.5 \\
\hline Nominal GDP (In millions of USD) & 3,210 & 3,630 & 3,917 & 3,520 & 3,704 & 4,000 & 4,298 & 4,614 \\
\hline
\end{tabular}

Sources: Guinean authorities; and staff estimates and projections.

$1 /$ Including debt-service payments on publicly guaranteed debt.

2/ In percent of exports of goods and nonfactor services. 
Table 6. Guinea: Millennium Development Goals

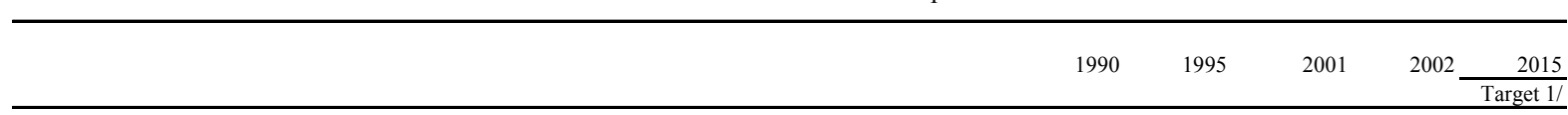

\section{Goal 1. Eradicate extreme poverty and hunger}

Target 1: Halve between 1990 and 2015, the proportion of people whose income is less than one dollar a day.

1. Population below US\$ 1 a day (percent)

2. Poverty gap ratio at US\$ 1 a day (percent)

3. Share of income or consumption held by poorest 20 percent (percent)

$\begin{array}{rrrrr}. . & 40.3 & 27.2 & . . & 20.0 \\ . . & . . & . . & . . & . . \\ . . & 6.4 & . . & . . & . .\end{array}$

Target 2: Halve, between 1990 and 2015, the proportion of people suffering hunger

4. Prevalence of child malnutrition (percent of children under 5)

5. Population below minimum level of dietary energy consumption (percent)

$\begin{array}{rrrrr}. . & . . & 9.0 & . . & 5.0 \\ 40.0 & 23.0 & 32.0 & . . & 15.0\end{array}$

Goal 2. Achieve universal primary education

Target 3: Ensure that, by 2015, children will be able to complete a full course of primary schooling

6. Net primary enrollment ratio (percent of relevant age group)

7. Percentage of cohort reaching grade 5

8. Youth literacy rate (percent age 15-24)

\section{Goal 3. Promote gender equality and empower women}

Target 4: Eliminate gender disparity in primary and secondary education preferably by 2005 and to all levels of education by 2015

9. Ratio of girls to boys in primary and secondary education (percent)

10. Ratio of young literate females to males (percent ages 15-24)

11. Share of women employed in the nonagricultural sector (percent)

12. Proportion of seats held by women in the national parliament (percent)

$\begin{array}{rrrrr}. . & 42.0 & 60.0 & . . & 100.0 \\ 58.8 & 54.1 & 84.4 & . . & . . \\ . . & . . & . . & . . & . .\end{array}$

Goal 4. Reduce child mortality

Target 5: reduce by two-thirds between 1990 and 2015, the under-five mortality rate

13. Under-five mortality rate (per 1,000 )

14. Infant mortality rate (per 1,000 live births)

15. Immunization against measles (percent of children under 12-months)

$\begin{array}{lllll}240.0 & 208.0 & 169.0 & . . & 90.0\end{array}$

$\begin{array}{llll}145.0 & 129.0 & 95.0 & . .\end{array}$

Goal 5. Improve maternal health

Target 6: Reduce by three-quarters, between 1990 and 2015, the maternal mortality ratio.

16. Maternal mortality ratio (modeled estimate, per 100,000 live births)

17. Proportion of births attended by skilled health personnel

$\begin{array}{rrrrr}700.0 & 650.0 & . . & . . & 220.0 \\ 30.5 & . . & 55.0 & . . & 95.0\end{array}$

Goal 6. Combat HIV/AIDS, malaria and other diseases

Target 7: Halt by 2015, and begin to reverse, the spread of HIV/AIDS

18. HIV prevalence among females (percent ages 15-24)

19. Contraceptive prevalence rate (percent of women ages 15-49)

20. Number of children orphaned by HIV/AIDS

Target 8: Halt by 2015, and begin to reverse, the incidence of malaria and other major diseases

21. Prevalence of death associated with malaria

22. Share of population in malaria risk areas using effective prevention and treatment

23. Incidence of tuberculosis (per 100,000 people)

24. Tuberculosis cases detected under DOTS (percent)

$\begin{array}{rrrrr}. . & . . & 2.5 & . . & . . \\ .0 & . . & 6.2 & . . & . . \\ . . & . . & 30,000 & . . & . .\end{array}$


Table 6 Guinea: Millennium Development Goals (concluded)

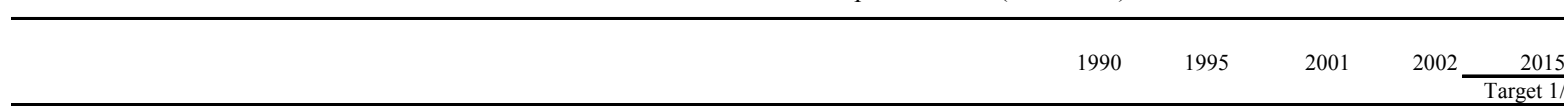

\section{Goal 7. Ensure environmental sustainability}

Target 9: Integrate the principles of sustainable development into policies and programs. Reverse the loss of environmental resources

25. Forest area (percent of total land area)

26. Nationally protected areas (percent of total land area)

27. GDP per unit of energy use (PPP \$ per kg oil equivalent)

28. $\mathrm{CO} 2$ emissions (metric tons per capita)

29. Proportion of population using solid fuels

Target 10: Halve by 2015 proportion of people without access to safe drinking water

29.6

Target 11: Achieve by 2020 significant improvement for at least 100 million slum dwellers

31. Access to improved sanitation (percent of population)

32. Access to secure tenure (percent of population)

Goal 8. Develop a Global Partnership for Development 2/

Target 16: Develop and implement strategies for productive work for youth.

45. Unemployment rate of population ages 15-24 (total) Female

Male

Target 17: Provide access to affordable essential drugs

46. Proportion of population access with access to affordable essential drugs

Target 18: Make available new technologies, especially information and communications

47. Fixed line and mobile telephones (per 1,000 people)

48. Personal computers (per 1,000 people)

Sources: Guinean authorities and United Nations

1/ Authorities' own objectives, as indicated in the 2005 report on the implementation of the MDGs.

2/ Targets 12-15 and indicators 33-44 are excluded because they can not be measured on a country specific basis.

These are related to official development assistance, market access, and the HIPC initiative. 
Conakry, May 31, 2005

Mr. Rodrigo de Rato

Managing Director

International Monetary Fund

Washington, D.C. 20431

USA.

Dear Mr. de Rato,

1. Guinea's economic situation in 2004 was characterized by weak economic growth and a sharp increase in inflation. In an unfavorable environment marked by ongoing tensions in neighboring countries, recurring electricity and water outages, and interruptions of cement supplies, macroeconomic management proved to be inadequate and macroeconomic imbalances worsened.

2. Since the beginning of this year, the government has further consolidated its economic management. It has also taken the necessary steps to complete the actions agreed with the IMF for the initiation of negotiations on a staff-monitored program.

3. The government intends to implement a staff-monitored economic and financial program during the period April 2005 to March 2006. The satisfactory execution of this program is a prerequisite for negotiating a new IMF-supported program through a PRGF.

4. The attached memorandum (Annex I) outlines the economic developments in 2004 and early 2005, as well as the economic and financial policies that the government intends to implement in order to achieve the macroeconomic and structural objectives that it has set itself for 2005 and the first quarter of 2006. The government undertakes to provide Fund staff with all the information needed to monitor the implementation of the measures envisaged in the program. A technical memorandum of understanding, which sets out the performance benchmarks for the program and specifies the type of data to be reported to the IMF, is also attached (Annex II).

5. The Guinean government believes that the policies and measures set forth in the attached memorandum are adequate to achieve the objectives of its program. If necessary, it stands ready to take any further measures that may become appropriate for this purpose. During the program period, the government will consult with the Managing Director, at its own initiative or whenever the Managing Director so requests, regarding Guinea's economic and financial policies.

6. In any event, in order to evaluate the progress achieved in program implementation, the IMF, in conjunction with the government of Guinea, will conduct an initial staff assessment by end-August 2005 based on the benchmarks for end-June 2005 and will 
perform a second staff assessment by end-November 2005 based on the benchmarks for endSeptember 2005. The government would wish to initiate the negotiations of a PRGFsupported program earlier than the allocated 12 months, if future staff assessments indicate that the program objectives have been reached more quickly than expected.

7. The Guinean government agrees to the publication of this letter, the government's memorandum on economic and financial policies for April 2005-March 2006, and the technical memorandum of understanding.

8. $\quad$ Please accept this letter with our highest regards.

Sincerely yours,

$/ \mathrm{s} /$

Mohamed Daffé

Governor of the BCRG /s/

Madikaba Camara

Minister of Economy and Finance

Attachments: - Memorandum on Economic and Financial Policies for the Period April 2005 - March 2006

- Technical memorandum of understanding 


\section{Memorandum on Economic and Financial Policies for the Period April 2005-March 2006}

\section{INTRODUCTION}

1. Guinea's economic situation in 2004 was characterized by a weak growth rate, stagnating investment and savings, and a sharp increase in inflation. In this unfavorable environment, macroeconomic management proved to be inadequate and macroeconomic imbalances worsened.

2. Accordingly, early this year the government began to implement tighter monetary and fiscal measures intended to stabilize the economy and the structural measures necessary to accelerate growth, reduce poverty, and lay a solid basis for achievement of the Millennium Development Goals (MDGs). By end-March 2005, fiscal results reflected the progress made in macroeconomic management, the National Assembly had adopted a tight budget for 2005, the exchange rate regime had been liberalized, and renewed efforts had been made by the central bank to implement the recommendations of the safeguards assessment report.

3. The government remains convinced of the need to step up its efforts to improve fiscal performance, remedy the monetary situation, and pursue structural reforms with the aim of restoring confidence in its determination to conduct sound macroeconomic policies, lay the bases for sustained growth of the Guinean economy, and take effective action to reduce poverty.

\section{RECENT ECONOMIC DEVELOPMENTS}

4. Macroeconomic imbalances remained substantial in 2004. The real GDP growth rate was 2.7 percent, which was nonetheless an improvement over the rate of 1.2 percent in 2003. This weak growth reflects inadequate macroeconomic management, which aggravated an unfavorable environment marked by ongoing tensions in neighboring countries, recurring electricity and water outages, and interruptions of cement supplies. With rapid growth of the money supply, largely as a result of bank financing of the government deficit, inflation increased considerably to an average annual rate of 17.5 percent. The external current account deficit (excluding grants) remained around 4 percent of GDP. The overall external deficit was financed mainly by a considerable accumulation of external arrears.

5. The deteriorating fiscal position could not be entirely corrected. To address the situation, in March 2004 the government had adopted a package of measures that included strengthening tax administration at all levels and collection of tax arrears, better control over exemptions, reduction of public services to a minimum, the freezing of certain budget appropriations, and strict adherence to budget procedures for commitment of expenditures. Nonetheless, owing to the insufficient implementation of these measures, it was not possible to fully remedy the situation notably because of certain extra budgetary spending, and the government found it necessary to take further measures in the fourth quarter of 2004. It 
established a commission for the collection of tax arrears, adopted a decree eliminating ad hoc exemptions, and adopted a supplementary budget law reducing budget allocations for nonpriority sectors. This package of measures enabled the government to curb the fiscal deterioration: revenues rose to the equivalent of 10.5 percent of GDP and primary current expenditure was held to 8.9 percent of GDP, about 2 percentage points of GDP less than in the previous year. The primary deficit was 0.5 percent of GDP, compared with a deficit of 2.5 percent in 2003, although this was below the targeted surplus of 1.6 percent of GDP included in the initial budget. The overall deficit (on a commitment basis, excluding grants) was 5.9 percent of GDP, versus the 2.6 percent expected in the initial budget. This deficit was covered primarily by bank financing and a considerable accumulation of external arrears.

6. Monetary policy was strongly influenced by the financing of the fiscal deficit. Financing of the fiscal deficit by central bank advances resulted in significant growth of base money and the money supply, despite the increased issuance of central bank sterilization bills (TRMs). By end-December 2004, the annual growth rate of broad money was 37 percent while the annual growth rate of base money was 33 percent. The net foreign assets of the central bank were negative, by approximately US\$6 million at year's end.

\section{During 2004, the government maintained its policy of fixing the Guinean} franc/U.S. dollar official exchange rate, although at a more depreciated rate since midJuly. After a series of depreciations totaling approximately 27.5 percent from mid-July through mid-September, the rate remained unchanged and the average spread between the official market rate and the parallel market rate was approximately 30 percent from midSeptember through end-December. Furthermore, in view of the inability of the official exchange market (MED) to satisfy the needs of the private sector, the central bank officially notified market participants that they should resort to foreign exchange bureaus to cover their foreign exchange requirements.

8. Progress on structural reforms was weak. Measures were taken during 2004 to adjust certain administered prices based on price changes on the international markets. Thus, the official price of rice was raised more than 50 percent and fuel prices were raised considerably, 67 percent for gasoline and 70 percent for diesel, along with an increase in public transportation prices. These adjustments enabled the government to reduce distortions in the marketing of these products and to limit their cost to the budget. Guinea plans to adhere to the Extractive Industries Transparency Initiative and, in late April 2005, it organized a national workshop on the Initiative toward this end. The National Assembly adopted the new banking law in April 2005. However, there was little progress in restructuring public enterprises (particularly electricity and water).

9. Guinea has had difficulties in covering its external debt service payments. External arrears accumulated through end-December 2004 were equivalent to US\$62.4 million. This total excludes certain deferred payments to Paris Club creditors. There have also been several delays in debt service payments to the IMF. 
10. Since early 2005, the government has resolutely tackled the macroeconomic imbalances and has taken the necessary steps to complete the agreed actions for the initiation of negotiations on a staff-monitored program. Thus,

- $\quad$ A tight fiscal policy for 2005 was adopted as reflected in the 2005 budget approved by the National Assembly on March 24. During the first quarter, the government made limited expenditures, while implementing measures enabling it to achieve its revenue targets, particularly by eliminating ad hoc exemptions.

- $\quad$ On March 1, 2005, the central bank abolished the foreign exchange auction market and established a unified exchange market system in which the exchange rate is determined by supply and demand among market participants.

- In the area of safeguards measures, a central bank audit committee was put in place in early February. Bids to undertake an audit of the central bank's international reserves and a financial audit of the bank itself were launched in April 2005. The terms of reference for these bids benefited from the Fund's comments.

- The restructuring of public enterprises, particularly electricity, water, and telephone, is among the priorities of the government program. In this context, the government has reinitiated its dialogue with its development partners, including the World Bank.

11. Macroeconomic performance has been relatively good in the first quarter of 2005. Inflation has stabilized at an annual rate of around 27 percent. The tax revenue target set for end-March was achieved. The level of committed expenditures was moderate due to the use of monthly provisional appropriations (douzièmes provisoires) pending the National Assembly's approval of the 2005 budget. This has yielded a near fiscal balance (on a commitment basis, grants included). The overall fiscal deficit on a cash basis, resulting mainly from the payment of obligations made in 2004, has been close to projections. The financing of the deficit as well as an increase in net foreign assets of the banking system, primarily deriving from the monetization of gold and the impact of the depreciation of the exchange rate, have led to a renewed acceleration of monetary growth. In the absence of an active open market operations policy, the annual rate of growth of the money supply rose from 37 percent as of end-December 2004 to 44.2 percent as of end-March 2005. The government settled US\$5.5 million in external arrears as of end-2004. However, because of the scarcity of foreign exchange, it was not able to service all its debt in the first quarter of 2005, accumulating a further US\$13.8 million in arrears, which it intends to settle before year-end 2005.

\section{ECONOMIC PROGRAM FOR 2005}

12. With the ultimate goal of setting up a three-year adjustment program supported by the Poverty Reduction and Growth Facility (PRGF), the government decided to implement a staff-monitored program for the period April 2005-March 2006. The program's primary goal is to restore macroeconomic stability over the course of 2005, taking 
into account the significant slippages observed in 2004. Real GDP growth is projected to be a modest 3 percent. In light of current international oil price levels, the government will take all appropriate measures to ensure Guinea's supply of petroleum products and full collection of the special tax on petroleum products consistent with the 2005 Budget Law. This policy's impact on prices will be offset by a monetary policy, targeted at reducing the inflation rate as measured by the consumer price index to slightly below 20 percent on a year-on-year basis. The external current account deficit, excluding official transfers, should be approximately 3 percent of GDP.

13. The program also includes structural reforms intended to support the macroeconomic stabilization efforts. These reforms, focusing primarily on tax administration, expenditure management, good governance, and revitalization of the privatization program, will enable the government to lay solid bases for subsequent measures intended to minimize the obstacles to sustained rapid growth and achievement of the Millennium Development Goals (MDGs).

\section{A. Government Finance}

14. Fiscal consolidation is a key element of the staff-monitored program. The primary objective is to increase the collection of domestic revenues by 1.7 percent of GDP and to cut government expenditures by 2.7 percent of GDP. This will make it possible to achieve a primary surplus of approximately 3 percent of GDP, 3.5 percentage points better than in 2004, to limit the overall deficit (commitment basis, excluding grants) to 1.7 percent of GDP, and to keep the use of bank financing in line with prudent monetary management.

15. Mining revenues should reach the equivalent of 3.1 percent of GDP, compared to 1.9 percent of GDP achieved in 2004. This increase is based on an expected increase in volumes extracted and prices of mining products, as well as on the strengthening of mining industry controls in strict compliance with the mining code and conventions.

16. Nonmining revenue is expected to increase by about 0.4 percent of GDP. This improvement is based on a broad range of measures summarized in Box 1. Specifically, it is a result of the application of the WAEMU common external tariff (CET) adopted during the first quarter of this year, as well as the implementation of measures recommended by IMF technical assistance missions to Guinea in 2004.

17. The 2005 budget reflects the government's determination to strictly control nonpriority expenditure and to increase spending directly related to poverty reduction. Primary current expenditure will be contained at 7.4 percent of GDP by controlling nonpriority spending, particularly transfers to the defense sector and expenditure involving missions abroad. Budget allocations for poverty reduction spending were set at 3.6 percent of GDP, up from the 3 percent achieved in 2004. The wage bill was fixed at 2.9 percent of GDP, down from 3.1 percent in 2004. The government also intends to settle external debt maturities due in 2005, and to reduce arrears. In order to do so, it is strengthening the 


\section{Box 1. Guinea: Key Measures for Improving Fiscal Performance in 2005}

\section{Customs administration}

- Apply the new Guinean customs tariff based on the WAEMU's CET, including the new categorization of goods and the effective elimination of the lump-sum taxation system, consumption surtaxes, and the fiscal surtax, as well as the ad hoc exemptions granted to certain agents.

- Eliminate ad hoc exemptions and exemptions linked to certain unjustified benefits and institute a ban on new ad hoc exemptions; tighten conditions for the granting of legal exemptions by means of specific implementing decrees, particularly in order to: (a) exclude products that are too difficult to control, (b) limit the duration of certain benefits, (c) institute strict quotas.

- $\quad$ Step up the monitoring of exemption regimes by (a) an exhaustive survey of beneficiaries, (b) improvement of interactions with the pertinent agencies and departments, and (c) on-site inspections of the use of exempted goods.

- $\quad$ Apply the transaction value in clearing goods through customs pursuant to Article VII of the WTO Agreement on Customs Valuation.

- Implement the recommendations on strengthening customs administration, particularly with respect to the specific status of customs agents, the status of contractual agents, the customs administration's use of its operating budget, and the abandonment of informal appointments.

\section{Tax administration}

- Improve coverage of tax audits by giving preference to targeted audits. The goal for 2005 is to achieve 30 percent coverage for large enterprises and 25 percent for medium-sized enterprises

- Adopt a program of reminders and penalties for delinquent taxpayers to reduce VAT delinquencies to less than 10 percent

- Implement a centralized procedure for tracking outstanding amounts and establish an action plan for their settlement

- $\quad$ Update the taxpayer master file of the large enterprise unit (SGE)

- Have an independent firm audit fisheries sector revenues

- Implement an action plan to strengthen tax administration based on the recommendations made by the IMF technical assistance mission of May-June 2004.

department responsible for debt management. The government will also strictly apply budget and accounting rules and procedures, specifically rejecting the practice of issuing promissory notes and other exceptional spending practices. It is also pursuing and strengthening the decentralization of budget appropriations, primarily in the priority sectors. The specific measures it plans to implement in 2005 are summarized in Box 2.

18. The government has initiated steps to stabilize the domestic debt situation. It will carry out an inventory of VAT credits payable, primarily to mining companies, and will negotiate refund schedules with these companies, principally through the securitization of these claims. This should enable the mining companies to once again be subject to VAT 


\section{Box 2. Guinea: Key Government Expenditure Management Measures}

- Integrate the defense sector into the medium-term expenditure framework, by setting budget ceilings and implementing a more rigorous and transparent review process.

- In order to control the wage bill, perform a physical inventory of civil servants at their posts, and then update the master files and personnel records, which are not managed by the Ministry of Finance and merge the civil service payroll and personnel master files.

- $\quad$ Require use of the computerized system for all expenditures and increase the capacity of the system by completing the interface with the Treasury.

- $\quad$ Establish a steering committee to supervise the operation of the computerized expenditure management system and prepare the terms of reference for an audit of the computer network.

- Amend Article 31 of the General Rules on Public Accounting in order to eliminate the possibility of extra budgetary expenditures.

- $\quad$ Continue efforts to extend the decentralization of budget appropriations to all priority sectors and all administrative regions and prefectures.

- Implement a system to track and forecast investment spending, and improve the public investment execution rate by adopting a law or regulation establishing the power of the various agencies involved in the process of preparing and executing public investments.

- $\quad$ Strengthen effective controls over services rendered and improve transparency in the management of public funds by ensuring compliance with government procurement procedures.

- $\quad$ Strengthen the capacity of government audit and control agencies to improve verification of government expenditures.

beginning in 2006. An inventory of cross debts between public enterprises and the government has also been undertaken and will be completed by end-July 2005 . This will make it possible to adopt a plan for the settlement of such cross debts before year's end, which will constitute a benchmark under the program.

19. The budget deficit financing structure promotes auctions of treasury bills over direct financing by the central bank. Central bank advances in 2005 will in no case exceed GNF 60 billion, against GNF 197.4 billion in 2004, and total bank financing will not exceed GNF 180 billion. In the first quarter of 2006, bank financing will not exceed GNF 50.3 billion, of which GNF 6.9 billion will be from the central bank and GNF 43.4 billion will be from commercial banks. The program also calls for negative nonbank financing in order to gradually eliminate the government's domestic debt. Foreign 
borrowing will be limited to concessional financing only. The financing gap in the amount of GNF 28.6 billion (US\$ 8.2 million) is expected to be covered by assistance from development partners.

\section{B. Monetary and Exchange Policy}

20. Under the program, the central bank will apply a restrictive monetary policy and effective management of bank liquidity in order to bring down the inflation rate and stem the loss of foreign assets. This policy will consist of limiting the growth of the money supply to below 3.5 percent each quarter from April 2005 to March 2006 in order to limit its annual growth rate to 13.8 percent at end-March 2006. In addition, the net foreign assets of the central bank will be increased to US\$35.5 million by end-March 2006. Effective control of base money will be achieved through issuance of Central Bank bills (TRMs) and through greater interest rate flexibility. Furthermore, bank liquidity management will be improved, primarily by enhancing its coordination with the Treasury's cash flow plan, and by implementing measures recommended by recent technical assistance missions from the IMF Monetary and Financial Systems Department. The government will also examine the possibility of issuing securities targeting the nonbank public.

21. The BCRG will continue implementing the measures recommended by the safeguards assessment report, in order to strengthen its financial statements and bring them into line with international standards for bank accounting. Specifically, the special audit of the foreign assets of the central bank will be completed by end-September 2005 and the financial audit of the central bank itself by end-December. Furthermore, all accounts held by individuals on the books of the central bank will be closed by end-2005. These three measures constitute benchmarks under the program. Furthermore, the government will continue its efforts to implement measures to combat money laundering and the financing of terrorism, particularly in terms of customer identification and know-your-customer guidelines for customers registered prior to the entry into force of the 2003 instructions. The draft anti-money laundering law has been submitted to the Ministry of Justice in April and should be finalized in October 2005.

22. In the area of bank supervision, the BCRG will monitor compliance with the prudential rules for all commercial banks through off-site examinations and on-site inspections and, if necessary, will impose sanctions on banks in violation. In this context, the BCRG will ensure that one bank in distress is recapitalized by end-December 2005. These supervision efforts will be extended to include the microfinance institutions subject to the new rules set out in various BCRG instructions. The government has submitted the draft microfinance law to the National Assembly, so that it may be reviewed and adopted. Harmonization of microfinance institution accounting systems will be pursued.

23. The government's priority is to strengthen the proper functioning of the foreign exchange market after its liberalization. The new foreign exchange regime should make the central bank's international reserves more secure and enhance the competitiveness of the Guinean economy. The ultimate goal of the reform is to create a unified foreign exchange 
market, reducing the role of the parallel exchange market and increasing the use of banks by enterprises and individuals. In light of the recommendations of the recent IMF technical assistance missions, the BCRG will rapidly adopt a number of structural measures to modernize the foreign exchange market; the principal measures are summarized in Box 3.

\section{Box 3. Guinea: Measures Concerning the Functioning of the Foreign Exchange Market}

- $\quad$ Creation at the central bank of a foreign exchange market committee comprising representatives of the central bank, deposit banks, and exchange bureaus.

- $\quad$ Daily reporting by banks and exchange bureaus of foreign exchange transactions, and buy and sell rates in the format recommended by the recent IMF technical assistance mission.

- Calculation of the weighted rate for the U.S. dollar and the euro against the GNF, based on reports received, to use as a reference rate. Prompt adoption of daily publication of the rate.

- Increase the circulation of information on the foreign exchange market, primarily by disclosing daily benchmark rates for foreign currencies against the GNF to the public.

- $\quad$ After consulting with foreign exchange market participants, promptly adopt a market operating convention.

- In-depth review of regulations governing foreign exchange policy together with the various government departments involved, the banking sector, and exchange bureaus; simplify and merge the various regulations.

- $\quad$ Strengthen the foreign exchange market regulatory authority in order to permit close monitoring of foreign exchange regulations, direct contact among the central bank, banks, and exchange bureaus, and continuous monitoring of market developments.

- $\quad$ Prompt repayment of the central bank's foreign exchange obligations to the banking sector. For future execution of operations for the repatriation of banknotes, contractual application of a value date beyond which remuneration will be paid by the central bank. Furthermore, banks will be obliged to repatriate all foreign exchange deriving from export transactions domiciled at their institution, or they will be subject to sanctions.

\section{STRUCTURAL REFORMS}

24. The government will pursue structural reforms to improve the quality and availability of public services and create an environment more conducive to sustainable growth, particularly by promoting the private sector. These reforms will concentrate on improving the supply of electricity and water and the telecommunications network, the restructuring and privatization of public enterprises, fighting corruption, and improving the justice system. 
25. One of the government's key priorities is the restructuring of the electricity, water, and telecommunications companies in order to foster regular, high-quality service, which is vital to stimulate growth. To this end, the government will adopt the following measures:

- $\quad$ Electricity sector: (i) definition of an overall strategy to stimulate the sector; (ii) adoption of a plan to combat fraudulent use of electricity; (iii) adoption of a plan to strengthen the financial situation of the electricity company; specifically, the government will sign an agreement with the electricity company (EDG) to settle cross debts by September 2005 and will not accumulate new payment arrears to the company; the government will contain its consumption of electricity under a package of technical and institutional measures (prepaid meters and verification of connections); (iv) completion of discussions in progress with the former private operators in the sector in order to resolve the financial disputes that arose out of the abandonment of prior agreements.

- Water sector: (i) definition of an overall strategy to increase access to drinking water; preparation and implementation of an action plan; (ii) strengthening of the mechanisms for coordinating and managing water resources; rapid adoption of implementing decrees for the water code; (iii) enhanced efficacy of managing drinking water at the institutional, technical, and commercial levels, including an agreement to settle cross debts by September 2005 and not to accumulate new arrears; (iv) adoption of a plan to combat fraud.

- $\quad$ Telecommunications sector: (i) establishment of a regulatory framework to stimulate private investment in the sector; (ii) search for a technical partner to replace the former partner.

26. The government has decided to revitalize its public enterprise privatization program to enable the private sector to participate more fully in the economic and social development of the country. The 2005 program focuses on the sale of shares and assets. First, the government will sell a portion or all of its holdings in seven companies: Banque Internationale pour le Commerce et l'Industrie de Guinée (BICIGUI), Banque Populaire Maroco-Guinéenne (BPMG), Union Générale des Assurances et Réassurances (UGAR), Société Mixte de Carburants Aéronautiques de Guinée (SOMCAG), Société Guinéo-Russe de carrières minières (SOGUIRUSSE), Société de Production d'Allumettes de Guinée (SOPRAG), and Société de Production Chimique (SOPROCHIM). It will also sell the assets of three enterprises: Société Mixte de Dragage (SOMIDRAT), a commercial enterprise (DIVERMA) and the movie theaters (ONACIG). These efforts will be continued during the period 2005-2008 with the planned privatization of some twenty enterprises. Finally, a third lot of some ten enterprises, primarily in the mining sectors, will be privatized after 2008 .

\section{The government will step up its efforts to strengthen governance and combat} corruption. The corruption and governance survey recently undertaken by the National Agency to Combat Corruption (ANLC) showed that corruption is widespread and found at 
all levels, to the extent that there is a risk of developing a culture of corruption. The results of this survey will be used to update the ANLC action plan, within the framework of the national strategy to combat corruption and promote good governance that will be adopted at the validation forum planned for September 2005. This will make it possible to simultaneously adopt an action plan to combat corruption, including concrete objectives and performance indicators, as well as specific actions to improve governance in key public sector activities and an implementation schedule, which will constitute a benchmark under the program. The complaints office for citizens, suppliers and users of public services, established in late April 2005, will play an important role in this effort. Moreover, the preparation of the anti-corruption draft law will be accelerated and the State Inspectorate General will pursue its investigations and the recovery of related revenue obligations. Furthermore, in order to reduce corruption and to promote use of the banking system, the government will eliminate the possibility of endorsing checks and will limit the use of cash to a certain ceiling for all transactions with the government.

28. The reform of the justice system will be intensified. Aware of the justice system's essential role in the poverty reduction strategy and the promotion of the private sector in the economy, the government, in collaboration with its development partners, will step up the reforms already underway. This primarily involves the implementation of the OHADA treaty's uniform acts, particularly on banking law, and the prompt adoption of the implementing regulations for five decrees on the organization of the justice system that were signed in March 2005.

\section{The Poverty Reduction Strategy}

29. The implementation of Guinea's poverty reduction strategy, as presented in its Poverty Reduction Strategy Paper (PRSP), has done much to improve the living standards of the population over the last two years despite an unfavorable macroeconomic environment. Progress has been significant in the areas of primary and pre-university education, health, village-level water resources, urban sanitation, and rural roads.

30. However, certain recent developments are cause for concern. Specifically, the expenditure cutbacks have affected government investment and nonwage expenditures in the social sectors. With the assistance of its development partners, Guinea finalized the second report on the implementation of the Millennium Development Goals (MDGs) in February 2005. This report concludes that much remains to be done and there is a risk that the MDGs may not be achieved in three areas: (i) elimination of extreme poverty and hunger; (ii) promotion of gender equality; and (iii) protection of the environment and access to drinking water. The government will prepare an action plan and its implementation beginning in 2006 should help it rise to the challenges in these three areas.

\section{The government will finalize the second PRSP progress report by end-June}

2005. This second report will present an update on the medium-term macroeconomic strategy and will discuss the results of the integrated basic survey for evaluating poverty in Guinea (EIBEP), the core welfare indicators questionnaire (CWIQ), the public expenditure tracking 
survey, the study of the integrated framework for trade, and other ad hoc surveys. The results will enable us to more precisely identify the causes of poverty in Guinea and to refine the PRS. The number of indicators to be monitored and assessed under the PRS that will serve as the basis for the preparation of the second progress report was reduced from 123 to 56 indicators. The necessary data on progress in 2004 and the challenges to be overcome were collected and the drafting of the preliminary report has begun.

\section{Program Monitoring}

\section{The monitoring of program implementation will be based on the indicative} targets for end-June, end-September, end-December 2005, and end-March 2006, as specified in Table 2, and on the structural measures specified in Table 1. The quantitative benchmarks under the program will include: (i) the floor for the primary fiscal balance; (ii) the ceiling for net credit to the government; (iii) the ceiling for base money; (iv) the floor for net foreign assets of the central bank; (v) new medium-term and long-term external debts contracted or guaranteed by the government or by the central bank; (vi) new short-term external debts contracted or guaranteed by the government or by the central bank; (vii) the non-accumulation of external debt payments arrears; (viii) nonmining revenues of the government; (ix) current expenditures of the government, excluding debt service; (x) the government's expenditures in priority sectors; and (xi) non-accumulation of domestic arrears. The attached technical memorandum of understanding sets forth the quantitative benchmarks and the terms underlying them. The implementation of the program and the results recorded in relation to these objectives will constitute a basis for evaluating the possibility of negotiating a new PRGF-supported program. The program will be subject to quarterly staff assessments conducted by the authorities and Fund staff; the first two will take place on the basis of data for end-June 2005 and end-September 2005.

33. During the period of the staff-monitored program, the Guinean government will not introduce new or intensify existing exchange restrictions, introduce any multiple currency practices, impose or intensify import restrictions for balance of payments reasons, or conclude bilateral payments agreements that are inconsistent with Article VIII of the Fund's Articles of Agreement. 
Table 1. Structural Benchmarks for the 2005-06 Staff-Monitored Program

\begin{tabular}{|c|c|c|}
\hline Areas & Measures & $\begin{array}{c}\text { Implementation } \\
\text { Date }\end{array}$ \\
\hline
\end{tabular}

Tax administration

- Adoption of an action plan with a timetable for strengthening tax and customs administration, based on the recommendations of the IMF technical assistance missions. End-June 2005

- Moratorium on new ad hoc tax or customs tariff exemptions

On a continuous basis

\section{Expenditure control}

- Establishment of a monitoring committee to review the operation of the computerized expenditure management system and prepare the terms of reference for a complete computer network audit

End-June 2005

- Amend Article 31 of the General Rules on Public Accounting in order to eliminate the possibility of extra budgetary transactions.

End-September 2005

- Launch a call for bids for an audit of the computerized expenditure management system

End-September 2005

- Closing of all accounts held by individuals on the books of the central bank

End-December 2005

- Completion of an audit of the government's domestic debt and of the cross debts between public enterprises and the government

End-December 2005

Fiscal issues regarding public enterprises

- Adoption by the Council of Ministers of an action plan to combat fraudulent use of electricity and drinking water

End-June 2005

- Adoption of an action plan to strengthen financially the electricity and water companies

End-September 2005

- Adoption of a plan to settle cross debts between public enterprises and the government.

End-December 2005 
Table 1. Structural Benchmarks for the 2005-06 Staff-Monitored Program (concluded)

\begin{tabular}{|c|c|c|}
\hline Areas & Measures & $\begin{array}{l}\text { Implementation } \\
\text { Date }\end{array}$ \\
\hline \multicolumn{3}{|c|}{ Safeguard measures } \\
\hline & $\begin{array}{l}\text { - Completion of the special audit of the central bank's } \\
\text { international reserves. }\end{array}$ & $\begin{array}{l}\text { End-September } \\
2005\end{array}$ \\
\hline & - Completion of the financial audit of the central bank itself. & $\begin{array}{l}\text { End-December } \\
2005\end{array}$ \\
\hline \multicolumn{3}{|l|}{ Governance } \\
\hline & $\begin{array}{l}\text { - Adoption of an action plan to combat corruption, including } \\
\text { concrete objectives and performance indicators, as well as } \\
\text { specific actions to improve governance in key public } \\
\text { sectors and an implementation schedule. }\end{array}$ & $\begin{array}{l}\text { End-September } \\
2005\end{array}$ \\
\hline \multicolumn{3}{|c|}{ Exchange rate regime } \\
\hline & $\begin{array}{l}\text { Refrain from introducing any new multiple currency } \\
\text { practices. }\end{array}$ & $\begin{array}{l}\text { On a continuous } \\
\text { basis }\end{array}$ \\
\hline
\end{tabular}


Table 2. Guinea: Quantitative Indicative Targets for the Staff-Monitored Program, 2004-06

\begin{tabular}{|c|c|c|c|c|c|c|}
\hline & \multirow[t]{3}{*}{2004} & \multicolumn{4}{|c|}{2005} & \multirow{2}{*}{2006} \\
\hline & & March & June & Sept. & Dec. & \\
\hline & & Prel. & \multicolumn{3}{|c|}{ Indicative targets } & \\
\hline & \multicolumn{5}{|c|}{ (In billions of Guinean francs) } & \\
\hline Central government primary balance (floor) 1 / & -40.3 & 125.0 & 186.0 & 259.7 & 331.5 & 116.9 \\
\hline Net bank credit to the government (ceiling) $2 / 3 /$ & 240.5 & 50.3 & 123.7 & 169.6 & 180.0 & 50.3 \\
\hline \multirow[t]{2}{*}{ Reserve money (ceiling) } & 763.3 & 907.5 & 926.2 & 942.5 & 959.6 & 976.9 \\
\hline & \multicolumn{5}{|c|}{ (In millions of U.S. dollars) } & \\
\hline Stock of net foreign assets of the central bank (floor) $4 / 5 /$ & -6.0 & 0.7 & 9.4 & 18.1 & 30.0 & 35.5 \\
\hline $\begin{array}{l}\text { New nonconcessional medium- or long-term external debt } \\
\text { contracted of guaranteed by the government or the central bank (ceil }\end{array}$ & 0.0 & 0.0 & 0.0 & 0.0 & 0.0 & 0.0 \\
\hline Outstanding stock of short-term external debt contracted or & 0.0 & 0.0 & 0.0 & 0.0 & 0.0 & 0.0 \\
\hline Stock of outstanding external payments arrears (ceiling) 6/ & 62.4 & 74.2 & 72.7 & 68.9 & 50.7 & 47.1 \\
\hline \multicolumn{7}{|c|}{ (In billions of Guinean francs) } \\
\hline Central government nonmining revenue $2 /$ & 765.0 & 246.4 & 498.0 & 742.7 & $1,002.9$ & 294.1 \\
\hline Central government noninterest current expenditure $2 /$ & 791.0 & 156.5 & 388.3 & 598.2 & 825.9 & 201.9 \\
\hline Expenditure in priority sectors $2 / 7 /$ & 263.9 & 71.8 & 181.2 & 280.8 & 399.0 & 96.0 \\
\hline Change in domestic arrears (a "-" sign indicates repayment) 2/ & 21.4 & 4.7 & 4.7 & 0.0 & 0.0 & 0.0 \\
\hline \multicolumn{7}{|l|}{ Memorandum items: } \\
\hline External budgetary assistance (in millions of US dollars) 2/ & 0.0 & 0.0 & 0.0 & 0.0 & 8.2 & 0.0 \\
\hline
\end{tabular}

1/ On a commitment basis; the domestic primary balance is defined as the difference between total revenue (excluding grants) and noninterest domestic expenditure, excluding foreign-financed capital expenditure.

2/ Cumulative from the beginning of the calendar year

3/ Subject to adjustment mechanisms for deviation in cash settlement of domestic arrears and disbursement of external budgetary assistance as specified in Technical Memorandum of Understanding (TMU).

4/ Subject to adjustment mechanisms for accumulation of new external arrears and deviation in disbursement of external budgetary assistance as specified in Technical Memorandum of Understanding (TMU).

5/ Excluding commercial credits.

6/ Excluding arrears under negotiation with creditors; monitored on a continuous basis.

7/ Priority sectors include public health, education, transport, road maintenance, justice, rural development, urban planning, and social affairs. This expenditure includes outlays funded by HIPC resources. 


\section{GUINEA}

\section{Technical Memorandum of Understanding}

May 31, 2005

\section{INTRODUCTION}

1. This memorandum sets out the understandings between the Guinean authorities and staff of the International Monetary Fund regarding the definitions of benchmarks of the staff monitored program and the related reporting requirements to facilitate program monitoring.

\section{DEFINITIONS}

\section{A. External Debt}

2. As specified in point 9 of the Guidelines on Performance Criteria with Respect to Foreign Debt adopted by the Executive Board of the IMF on August 24, 2000, ${ }^{18}$ for purposes of the program, "debt" will be understood to mean current, i.e., not contingent, liability, created under a contractual arrangement through the provision of value in the form of assets (including currency) or services, and which requires the obligor to make one or more payments in the form of assets (including currency) or services, at some future point(s) in time; these payments will discharge the principal and/or interest liabilities incurred under the contract. Debt can take a number of forms, the primary ones being the following:

- loans: advances of money to the obligor by the lender on the basis of an undertaking that the obligor will repay the funds in the future (including deposits, bonds, debentures, commercial loans, and buyers' or suppliers' credits) and temporary exchanges of assets that are equivalent to fully collateralized loans under which the obligor is required to repay the funds, and usually pay interest, by repurchasing the collateral from the buyer in the future (such as repurchase agreements and official swap arrangements);

- $\quad$ suppliers' credits: contracts where the supplier permits the obligor to defer payments until some time after the date on which the goods are delivered or services are provided; and

\footnotetext{
${ }^{18}$ See EBS/00/128 (6/30/00)_ “"Limits on External Debt or Borrowing in Fund Arrangements-Proposed Change in Coverage of Debt Limits."
} 
- leases: arrangements under which property is provided that the lessee has the right to use for one or more specified period(s) of time, which are usually shorter than the total expected service life of the property, while the lessor retains the title to the property. For the purpose of this memorandum, the debt is the present value (at the inception of the lease) of all lease payments expected to be made during the period of the agreement, excluding those payments that cover the operation, repair, or maintenance of the property.

3. Under this definition of debt, arrears, penalties, and judicially awarded damages arising from failure to make payment under a contractual obligation that constitutes debt are debt. Failure to make payment on an obligation that is not considered debt under this definition (e.g., payment on delivery) will not give rise to debt.

\section{B. Concessionality of External Debt}

4. Debt is considered concessional if it has a grant element equivalent to 35 percent or more using the available currency-specific commercial interest reference rate (CIRR) and following the methodology approved by the IMF Executive Board.

\section{Domestic Debt}

5. The domestic debt includes all current - and unconditional—obligations arising from a contractual agreement concluded or guaranteed by the Guinean government with a resident partner, as the counterpart to an interest that may take the form of assets (including cash) or services and by virtue of which the obligor must subsequently make one or several payments in the form of assets (including cash) or services in repayment of the principal and/or interest arising from the contractual obligation.

\section{Cash Relief from External Debt Relief}

6. For the purpose of the program, the only debt relief that will be subject to the adjustment mechanisms described below is one that leads to an effective reduction in programmed debt service. This excludes debt relief given on debt that has been in drawnout rescheduling/restructuring negotiations with non-Paris Club creditors and for which no debt service has been paid in the past year, for example, debts to be considered under the debt-and debt-service-reduction operation with commercial creditors, and for which no provision in debt service has been explicitly made in the fiscal program (except for upfront costs). While this includes traditional external debt relief, it also excludes the assistance provided under the enhanced Heavily Indebted Poor Countries (HIPC) Initiative. 


\section{E. Government}

7. Unless otherwise noted, the government is meant to include the central government. Local governments are excluded from the definition of government. The units covered under the central government correspond to those listed in the government flow of funds table (TOFE).

\section{F. Program Exchange Rate}

8. Amounts denominated in SDRs will be converted to U.S. dollars at the fixed exchange rate of US\$1.5 per SDR, and converted into Guinean francs at the fixed exchange rate of US $\$ 1=\mathrm{GF} 3,150$. IMF liabilities, in particular, which are included in the definition of net foreign assets, will be valued at these fixed exchange rates. Any deviations resulting from the variations between these fixed and actual exchange rates will lead to a full upward or downward adjustment, as appropriate, in the valuation of the net foreign assets of the central bank for the purpose of assessing the respect of the benchmark on the net foreign assets of the central bank.

\section{G. Public Accounts with the Central Bank of the Republic of Guinea and Primary Banks}

9. The net treasury position (NTP) vis-à-vis the Central Bank and the primary banks is determined by credit and debit flows reported on all accounts belonging to the central government, local administrations, public development projects and programs, public entities, and counterpart funds. It covers a broader area than the central government budget, which results in a gap between the financing of budget operations and net flows of public accounts entering in the determination of the NTP.

10. This gap is reported in the government flow of funds table (TOFE) as an adjustment item, owing to the replacement of bank financing by the NTP. To make this adjustment item more explicit, it is necessary to set up tables of the flows in so-called "satellite" accounts located at the Central Bank of the Republic of Guinea and in commercial banks. For the purpose of the program, such tables should be attached to the TOFE.

\section{H. Privatization Receipts}

11. For the purpose of this memorandum, privatization receipts will be understood to mean all monies received by the government through the sale or concessioning of a public company, organization, or facility to a private company or companies, organization(s), or individual(s). To the extent possible, receipts should be presented on gross basis; if costs are incurred in the sale or concessioning, they should be recorded separately as expenditure. 


\section{QUANTITATIVE BENCHMARKS}

\section{A. Central Government Primary Balance}

\section{Definition}

12. The primary budget balance (commitment basis) is calculated as total government revenue, excluding foreign grants and privatization proceeds (counted as financing), less noninterest domestic expenditure, excluding foreign-financed investment expenditure.

\section{Indicative target}

13. The floor on the primary budget balance, cumulative from the beginning of each calendar year, is set at Guinean francs (GF) 186.0 billion at June 30, 2005, GF 259.7 billion at September 30, 2005, GF 331.5 billion at December 31, 2005, and GF 116.8 billion at March 31, 2006. These floors represent an indicative target at end-June, end-September, and endDecember 2005, as well as at end-March 2006.

\section{Reporting deadlines}

14. Data on the primary budget balance (commitment basis) will be forwarded monthly by the Ministry of Economy and Finance within 30 days following the end of each month.

\section{B. Net Claims of the Banking System on the Government}

\section{Definition}

15. Net claims of the banking system on the government comprise the stock of all outstanding claims of the domestic banking sector on the government (loans, advances, and all other government debt instruments, such as government securities) less all deposits held by the government with the domestic banking system.

16. Net claims of the banking system on the government are calculated by the Central Bank of the Republic of Guinea, whose figures are deemed valid within the context of the program, after review by the Treasury.

\section{Indicative target}

17. The ceiling on the change in net claims of the banking system on the government, cumulative from the beginning of each calendar year, is set at Guinean francs (GF) 123.7 billion at June 30, 2005, GF 169.6 billion at September 30, 2005, GF 180.0 billion at December 31, 2005, and GF 50.3 at March 31, 2006. These ceilings represent an indicative target at end-June, end-September, and end-December 2005, as well as at end-March 2006. 


\section{Adjustment}

18. The ceilings on the cumulative changes in net claims of the banking system on the government will be subject to adjustment if disbursements of external budgetary assistance (including debt relief as defined above), exceed or fall short of program forecasts. The indicative target will be adjusted (i) upward for a shortfall in exceptional external financing up to an amount equivalent to 75 percent of the shortfall; and (ii) downward for the full amount of any excess in external assistance.

19. For the purpose of the program, the indicative target on net claims of the banking system on the government will be adjusted downward for the full amount of any net accumulation of domestic arrears.

20. For the purpose of the program, the indicative target on net claims of the banking system on the government will be adjusted downward (upward) by the amount of government securities held by the banking system on March 31, 2005 and sold to (purchased from) the nonbank financial system and/or the public from April 1, 2005 onward.

\section{Reporting deadlines}

21. Data on net claims of the banking system on the government will be forwarded monthly by the Central Bank of the Republic of Guinea within 30 days following the end of each month.

\section{Reserve Money}

\section{Definition}

22. Reserve money comprises bank reserves and deposits of the private sector with the central bank, as well as cash in circulation.

\section{Indicative target}

23. The ceiling on reserve money is set at Guinean francs (GF) 926.2 billion at June 30, 2005, GF 942.5 billion at September 30, 2005, GF 959.6 billion at December 31, 2005, and GF 976.9 at March 31, 2006. These ceilings represent a benchmark at end-June, endSeptember, and end-December 2005, as well as at end-March 2006.

\section{Reporting deadlines}

24. Data on reserve money will be forwarded monthly by the Central Bank of the Republic of Guinea within 30 days following the end of each month. 


\section{Net Foreign Assets of the Central Bank}

\section{Definition}

25. Net foreign assets of the Central Bank of the Republic of Guinea include the official reserves of the central bank net of external obligations. They comprise holdings of monetary gold, the reserve position in the International Monetary Fund, SDR holdings, and short- and long-term foreign assets, net of external obligations. They exclude the amounts pledged or otherwise encumbered.

\section{Indicative target}

26. The floor on net foreign assets of the Central Bank of the Republic of Guinea is set at U.S. dollars 9.4 million at June 30, 2005, U.S. dollars 18.1 million at September 30, 2005, U.S. 30.0 million at December 31, 2005, and U.S. dollars 35.5 at March 31, 2006. These floors represent an indicative target at end-June, end-September, end-December 2005, as well as at end-March 2006.

\section{Adjustment}

27. The floor on net foreign assets of the Central Bank of the Republic of Guinea will be subject to adjustment if disbursements of external budgetary assistance (including debt relief as defined above) exceed or fall short of program forecasts. The quantitative benchmark will be adjusted (i) downward for a shortfall in exceptional external financing up to an amount equivalent to 75 percent of the shortfall; and (ii) upward for the full amount of any excess in external assistance.

28. The floor on net foreign assets of the Central Bank of the Republic of Guinea will be adjusted upwards for any new accumulation of external payment arrears, or cash settlement of such arrears inferior to the program projections.

\section{Reporting deadlines}

29. Data on net foreign assets of the Central Bank of the Republic of Guinea will be forwarded monthly by the Central Bank of the Republic of Guinea within 30 days following the end of each month.

\section{E. Nonconcessional Foreign Loans Contracted or Guaranteed by the Government or the Central Bank}

\section{Indicative target}

30. The Government and the Central Bank of the Republic of Guinea undertake not to contract or guarantee any foreign loans maturing in one year or more, with a grant element of less than 35 percent (as defined above). This benchmark applies not only to debt as defined in point 9 of the Guidelines on Performance Criteria with Respect to Foreign Debt, adopted by 
the IMF's Executive Board on August 24, 2000, ${ }^{19}$ but also to commitments contracted or guaranteed for which value has not been received. However, this benchmark does not apply to financing granted by the Fund. This obligation is a benchmark to be observed continuously.

\section{Reporting deadlines}

31. Details on any government or central bank loan (terms of the loan and creditors) must be reported within 30 days of the end of each month. The same requirement applies to guarantees extended by the government and/or the Central Bank of the Republic of Guinea.

\section{F. Short-Term External Debt of the Government or the Central Bank}

\section{Benchmark}

32. The government and the Central Bank of the Republic of Guinea undertake not to contract or guarantee any new external debt with a contractual maturity of less than one year. This benchmark applies not only to debt as defined in point 9 of the Guidelines on Performance Criteria with Respect to Foreign Debt, adopted by the IMF's Executive Board on August 24, 2000, ${ }^{20}$ but also to commitments contracted or guaranteed for which value has not been received. Excluded from this benchmark are normal import-related commercial credits and changes in deposits from international bodies. This obligation is a benchmark to be observed continuously. As of March 31, 2005, the government of Guinea and the Central Bank of the Republic of Guinea had no short-term external debt.

\section{Reporting deadlines}

33. Details on any new government or central bank short-term external debt (terms of the loan and creditors) must be reported within 30 days of the end of each month. The same requirement applies to short-term guarantees extended by the government and/or the Central Bank of the Republic of Guinea.

\section{G. Nonaccumulation of External Payment Arrears}

\section{Definition}

34. External arrears of the government or the Central Bank of the Republic of Guinea consist of all debt-service obligations (principal and interest) arising in respect of loans contracted or guaranteed by the government or the Central Bank of the Republic of Guinea that are due but not paid on the due date, and unpaid penalties or interest charges associated

\footnotetext{
${ }^{19}$ See paragraph 2.

${ }^{20}$ Ibid.
} 
with these arrears. Thus defined, the stock of external arrears as of March 31, 2005 amounted to US dollars 72.9 million.

\section{Benchmark}

35. Under the program, the government and the Central Bank of the Republic of Guinea undertakes not to accumulate external payment arrears on government and/or central bank debt, with the exception of external payment arrears arising from government and/or central bank debt being renegotiated with external creditors, including Paris Club creditors. This nonaccumulation is a performance criterion to be observed continuously.

36. The government and the Central Bank of the Republic of Guinea also commit to reduce the stock of external arrears to US\$69.1 million by September 30, 2005, to US $\$ 50.0$ million by December 31, 2005, and US\$ 46.4 million by March 31, 2006. These ceilings on the stock of external arrears represent benchmarks at end-September 2005, endDecember 2005, and end-March 2006.

\section{Reporting deadlines}

37. Data on outstanding balances, accumulation, and repayment of external payment arrears will be forwarded within 30 days following the end of each month.

\section{H. Central Government Nonmining Revenue}

\section{Definitions}

38. Government revenue includes tax, nontax revenue, and capital revenue. Tax and nontax revenue are defined in accordance with Government Finance Statistics (GFS) 1986, section IV.A.1, using the following categories. For tax revenue, the main categories are taxes on income, profit and capital gains (Title 1); taxes on property (Title 2); taxes on international trade (Title 3), including import duties, the export duty (droit fiscal de sortie), the surtax on consumption, the liquidation levy (redevance de liquidation) and penalties related to international trade; taxes on goods and services (Title 4), including general sales taxes, valueadded taxes on domestic sales and on imports, the single tax on vehicles (TUV), the TAF, taxes on petroleum products, and (export) taxes on mining products, including the tax on mining products, taxes on diamonds, and taxes on precious metals. Other tax revenue include stamp taxes and revenue from recording taxes. Tax receipts also incorporate the taxes assumed by the State. Nontax revenue is defined as property income, including dividends, revenue from fishing licenses, revenue from the sale of telephone licenses, revenue from the rental of infrastructure, revenue for services rendered, administrative duties and fees and other receivables. For the purpose of the program, capital revenue includes revenue from the sale of fixed assets, excluding revenue from privatization (which is presented as a separate item), and includes repayment of loans by public enterprises.

39. For the purpose of the program, central government nonmining revenue is defined as the sum of (i) taxes on revenue and profits (Title 1) minus the income tax paid by mining 
companies; (ii) taxes on property (Title 2); other tax receipts (Title 5); (iii) taxes on goods and services minus the proceeds from taxes on mining products (Title 4, Chapter 42); taxes on international trade (Title 3); and nontax revenue pertaining to Titles 6, 7, and 8 excluding privatization proceeds, fees paid by the diamond purchase centers (61.21) and mining fees (61.31).

\section{Benchmark}

40. The floor on central government nonmining revenue, cumulative from the beginning of each calendar year, is set at Guinean francs (GF) 498.0 billion at June 30, 2005, GF 742.7 billion at September 30, 2005, GF 1,000.9 billion at December 31, 2005, and GF 294.1 at March 31, 2006. These floors represent a benchmark at end-June, end-September, and end-December 2005, as well as at end-March 2006.

\section{Reporting deadlines}

41. Data on government revenue will be forwarded monthly by the Ministry of Economy and Finance within 30 days of the end of each month.

\section{Central Government Noninterest Current Expenditure}

\section{Definition}

42. Central government noninterest current expenditure is defined as total fiscal expenditure minus outlays for domestic and external debt service, investment expenditures, net lending, and restructuring expenditures.

\section{Benchmark}

43. The ceiling on central government noninterest current expenditure, cumulative from the beginning of each calendar year, is set Guinean francs (GF) 388.3 billion at June 30, 2005, GF 598.2 billion at September 30, 2005, GF 825.9 billion at December 31, 2005, and GF 201.9 at March 31, 2006. These ceilings represent a benchmark at end-June, end-September, and end-December 2005, as well as at end-March 2006.

\section{Reporting deadlines}

44. Data on government expenditure will be forwarded monthly by the Ministry of Economy and Finance within 30 days of the end of each month. 


\section{J. Central Government Current Expenditure in Priority Sectors}

\section{Definition}

45. The priority sectors include public health, education, transport, road infrastructure, justice, rural development (agriculture, fisheries, livestock, and village-level water resources), urban planning, and social affairs. For the purpose of the program, expenditure in priority sectors shall include spending under Title 2 (wages and salaries), Title 3 (goods and services), Title 4 (transfers and subsidies), Title 5 (domestically financed investment) and Title 6 (capital transfers), excluding expenditures under Title 4, Title 5, and Title 6 related to higher education, but including expenditures financed by resources made available under the HIPC Initiative.

\section{Benchmark}

46. The floor on central government expenditure in priority sectors, including expenditures financed by resources made available under the HIPC Initiative, cumulative from the beginning of each calendar year, is set at Guinean francs (GF) 181.2 billion at June 30, 2005, GF 280.8 billion at September 30, 2005, GF 399.0 billion at December 31, 2005, and GF 96.0 at March 31, 2006. These floors represent a benchmark at end-June, endSeptember, and end-December 2005, as well as at end-March 2006.

\section{Reporting deadlines}

47. Data on central government expenditure in priority sectors will be forwarded monthly by the Ministry of Economy and Finance within 30 days of the end of each month.

\section{K. Nonaccumulation of Domestic Arrears}

\section{Definition}

48. Domestic payment arrears are defined as follows:

- For all obligations having a contractual due date, the arrear arises by non-payment on the due date;

- $\quad$ For expenditures that are treated through the normal procedure, the non-payment, in cash, by bank transfer, or any other legal means of settlement, including through compensations, within 90 days from the date when the payment order was issued, generates an arrear;

- Tax credits confirmed by the proper authorities after review, and not paid within 60 days from the date of confirmation, are considered arrears;

- All other obligations arising from unexpected events or from a decision of the proper public authorities, such as indemnities for expropriations, public enterprise restructuring 
associated with social plans, whose payments have not been made within the timeframe specified in the subsequent legal acts, are considered arrears.

\section{Benchmark}

49. The government will not accumulate any domestic payment arrears on a net basis, starting on April 1, 2005. This non accumulation is a benchmark to be observed continuously. Furthermore, during the third quarter of 2005, the government will pay GF 4.7 billion of domestic arrears accumulated during the first quarter of 2005.

\section{Reporting deadlines}

50. Data on outstanding balances, accumulation, and repayment of domestic arrears will be reported by the Ministry of Economy and Finance within 30 days following the end of each month.

\section{Structural Benchmarks}

\section{Benchmark}

51. The following three measures will serve as structural benchmarks for end-June 2005:

- Adoption of an action plan with a timetable for strengthening tax and customs administration, based on the recommendations of the IMF technical assistance missions;

- $\quad$ Establishment of a monitoring committee to review the operation of the computerized expenditure management system and prepare the terms of reference for a complete computer network audit;

- Adoption by the Council of Ministers of an action plan to combat fraudulent use of electricity and drinking water.

52. The following four measures will serve as structural benchmarks for end-September 2005:

- Amend Article 31 of the General Rules on Public Accounting in order to eliminate the possibility of extra budgetary transactions;

- $\quad$ Launch a call for bids for an audit of the computerized expenditure management system;

- Adoption of an action plan to strengthen financially the electricity and water companies; 
- Adoption of an action plan to combat corruption, including concrete objectives and performance indicators, as well as specific actions to improve governance in key public sectors and an implementation schedule.

- $\quad$ Completion of the special audit of the Central Bank's international reserves.

53. The following four measures will serve as structural benchmarks for end-December 2005.

- $\quad$ Adoption of a plan to settle cross debts between public enterprises and the government;

- Closing of all accounts held by individuals on the books of the central bank;

- Completion of an audit of the government's domestic debt and of the cross debts between public enterprises and the government;

- $\quad$ Completion of the financial audit of the central bank itself.

54. The following two measures will serve as structural benchmarks on a continuous basis:

- Moratorium on new ad hoc tax or customs tariff exemptions;

- $\quad$ Refrain from introducing any new multiple currency practices.

\section{Reporting deadlines}

55. The information concerning the implementation of these structural benchmarks will be reported to the Fund within two weeks following their scheduled implementation date.

\section{REPORTING REQUIREMENTS}

56. The authorities will send the data in Table 1 to the Fund within the time limits set out in that table. Barring any indication to the contrary, the data will take the form mutually agreed by the authorities and the IMF. The authorities will supply the Fund with any additional information that the Fund requests in connection with monitoring performance under the program on a timely basis.

57. The status of implementation of all structural measures pertaining to the program will be transmitted to the IMF's African Department within 30 working days after the end of each month. 


\section{Table 1. Guinea: Data Reporting Requirements}

\begin{tabular}{|c|c|c|c|}
\hline $\begin{array}{l}\text { Category of } \\
\text { Data }\end{array}$ & Table/Report & Frequency & Deadline \\
\hline \multirow[t]{4}{*}{$\begin{array}{l}\text { Financial and } \\
\text { monetary data }\end{array}$} & $\begin{array}{l}\text { Central bank balance sheet, consolidated commercial bank, } \\
\text { balance sheet, monetary survey. }\end{array}$ & Monthly & $\begin{array}{l}\text { 30th of the month for the previous } \\
\text { month }\end{array}$ \\
\hline & Interest rates. & Monthly & $\begin{array}{l}30^{\text {th }} \text { of the month for the previous } \\
\text { month }\end{array}$ \\
\hline & $\begin{array}{l}\text { HIPC Initiative Central Bank of Republic of Guinea account } \\
\text { transactions. }\end{array}$ & Monthly & $\begin{array}{l}30^{\text {th }} \text { of the month for the previous } \\
\text { month }\end{array}$ \\
\hline & Detailed NTP and NGP. & Monthly & $\begin{array}{l}30^{\text {th }} \text { of the month for the previous } \\
\text { month }\end{array}$ \\
\hline \multirow[t]{6}{*}{ Fiscal data } & $\begin{array}{l}\text { Table of indicators (tableau de bord), including details on } \\
\text { revenues, expenditures, financing, and cash-flow operations. }\end{array}$ & Monthly & $\begin{array}{l}30^{\text {th }} \text { of the month for the previous } \\
\text { month }\end{array}$ \\
\hline & Treasury balances (balances générales du Trésor). & Monthly & $\begin{array}{l}30^{\text {th }} \text { of the month for the previous } \\
\text { month }\end{array}$ \\
\hline & Cash-flow plans (plan de trésorerie). & Monthly & $\begin{array}{l}30^{\text {th }} \text { of the month for the previous } \\
\text { month }\end{array}$ \\
\hline & Monthly government flow of funds table (TOFE). & Monthly & $\begin{array}{l}30^{\text {th }} \text { of the month for the previous } \\
\text { month }\end{array}$ \\
\hline & $\begin{array}{l}\text { Monthly expenditure reports by ministries in expenditure circuit } \\
\text { (chaîne des dépenses). }\end{array}$ & Monthly & $\begin{array}{l}30^{\text {th }} \text { of the month for the previous } \\
\text { month }\end{array}$ \\
\hline & HIPC Initiative spending plans and budget execution. & Monthly & $\begin{array}{l}30^{\text {th }} \text { of the month for the previous } \\
\text { month }\end{array}$ \\
\hline \multirow[t]{2}{*}{$\begin{array}{l}\text { Real sector } \\
\text { data }\end{array}$} & Consumer price index, Conakry. & Monthly & $\begin{array}{l}30^{\text {th }} \text { of the month for the previous } \\
\text { month }\end{array}$ \\
\hline & National accounts. & Annual & $\begin{array}{l}\text { Summary estimates: three months } \\
\text { after the end of year }\end{array}$ \\
\hline \multirow[t]{3}{*}{$\begin{array}{l}\text { Balance of } \\
\text { payments data }\end{array}$} & Imports by use and exports by major product, trade balance. & Monthly & $\begin{array}{l}\text { 30th of the month for the previous } \\
\text { month }\end{array}$ \\
\hline & Price and volume indices of imports and of exports. & Quarterly & One month after end of quarter \\
\hline & Consolidated estimates of the balance of payments. & Annual & $\begin{array}{l}\text { Summary estimates: six months } \\
\text { after the end of year }\end{array}$ \\
\hline \multirow[t]{5}{*}{ External debt } & Debt service due before and after debt relief. & Monthly & $\begin{array}{l}30^{\text {th }} \text { of the month for the previous } \\
\text { month }\end{array}$ \\
\hline & Cash debt service paid. & Monthly & $\begin{array}{l}\text { 30th of the month for the previous } \\
\text { month }\end{array}$ \\
\hline & Debt service reconciliation table. & Monthly & $\begin{array}{l}\text { 30th of the month for the previous } \\
\text { month }\end{array}$ \\
\hline & Stock of outstanding debt and arrears. & Monthly & $\begin{array}{l}\text { 30th of the month for the previous } \\
\text { month }\end{array}$ \\
\hline & Drawings on new loans. & Monthly & $\begin{array}{l}\text { 30th of the month for the previous } \\
\text { month }\end{array}$ \\
\hline \multirow[t]{2}{*}{$\begin{array}{l}\text { External grants } \\
\text { and loans }\end{array}$} & Disbursements. & Monthly & $\begin{array}{l}\text { 30th of the month for the previous } \\
\text { month }\end{array}$ \\
\hline & $\begin{array}{l}\text { Monthly transfer of HIPC debt relief to the HIPC account of the } \\
\text { central bank (compte générique) }\end{array}$ & Monthly & $\begin{array}{l}\text { 30th of the month for the previous } \\
\text { month }\end{array}$ \\
\hline
\end{tabular}




\section{Guinea: Relations with the Fund}

(As of March 31, 2005)

I. Membership Status: Joined on September 28, 1963; Article VIII

II. General Resources Account:

Quota

Fund holdings of currency

Reserve position in Fund

III. SDR Department:

Net cumulative allocation

Holdings

IV. Outstanding Purchases and Loans:

Poverty Reduction and Growth Facility (PRGF) arrangements

\begin{tabular}{rr} 
SDR million & Percent of Quota \\
\hline 107.10 & 100.00 \\
107.03 & 99.93 \\
0.08 & 0.07
\end{tabular}

SDR million Percent of Allocation

17.60

100.00

0.00

0.00

$\underline{\text { SDR million }}$

72.94

$\underline{\text { Percent of Quota }}$

68.11

V. Financial Arrangements:

Type $\quad \underline{\text { Approval date }}$ Expiration date Amount approved

(SDR million)

Amount drawn

$\mathrm{PRGF}^{1}$

$05 / 02 / 2001$

$05 / 01 / 2004$

64.26

(SDR million)

ESAF/PRGF

$01 / 13 / 1997$

$01 / 12 / 2001$

70.80

25.70

ESAF

$11 / 06 / 1991$

$12 / 19 / 1996$

57.90

62.94

46.32

VI. Projected Payments to the Fund (without HIPC Assistance)

(SDR million; based on existing use of resources and present holdings of SDRs):

\begin{tabular}{lrrrrr} 
& \multicolumn{5}{c}{ Forthcoming } \\
\cline { 2 - 6 } Principal & $\underline{2005}$ & $\underline{2006}$ & $\underline{2007}$ & $\underline{2008}$ & $\underline{2009}$ \\
Charges/interest & 11.83 & 13.09 & 13.98 & 11.83 & 8.29 \\
Total & $\underline{0.67}$ & $\underline{0.71}$ & $\underline{0.64}$ & $\underline{0.58}$ & $\underline{0.53}$ \\
& $\underline{12.50}$ & $\underline{13.80}$ & $\underline{14.62}$ & $\underline{12.41}$ & $\underline{8.81}$
\end{tabular}

\footnotetext{
${ }^{1}$ The PRGF went off track as of end-December 2002.
} 


\section{Implementation of HIPC Initiative:}

A. Commitment of HIPC assistance

Decision point date

Assistance committed by all creditors(US\$ million) ${ }^{2}$

Of which: IMF assistance (US\$ million)

(SDR equivalent in millions)

Completion point date

B. Disbursement of IMF assistance (SDR million)

Amount disbursed to the member

Interim assistance

Completion point balance

Additional disbursement of interest income ${ }^{3}$
Enhanced

Framework

$12 / 20 / 2000$

545.00

31.40

24.24

Floating

Total disbursements

\section{Safeguards Assessments:}

An on-site safeguards assessment of the BCRG was completed on July 11, 2002; it concluded that substantial risks existed in the central bank's external audit mechanism, financial reporting framework, and system of internal controls. The authorities have yet to implement all the corrective actions recommended.

\footnotetext{
${ }^{2}$ Assistance committed under the original framework is expressed in net present value (NPV) terms at the completion point, and assistance committed under the enhanced framework is expressed in NPV terms at the decision point.

${ }^{3}$ Under the enhanced framework, an additional disbursement is made at the completion point corresponding to interest income earned on the amount committed at the decision point but not disbursed during the interim period.
} 


\section{Exchange Arrangements:}

On March 1, 2005, the Guinean authorities liberalized the foreign exchange system by abandoning their artificial official exchange rate auction. The Central Bank has been taking as a reference rate the arithmetic average of rates quoted weekly by deposit banks. Since May 25, the Central Bank has started to include foreign exchange bureaus in the calculation of the reference rate. The upcoming Article IV consultation will examine whether all multiple currency practices have been completely eliminated.

\section{Article IV Consultation:}

Guinea is on the 12-month cycle. The last consultation was concluded by the Executive Board on August 27, 2004 (Country Report No. 04/392).

XI. Technical Assistance: ${ }^{4}$

Department

FAD

FAD/resident advisor

FAD/resident advisor

FAD

FAD

FAD

FAD

MFD/resident advisor

MFD

MFD

MFD

\section{Purpose}

Advise on customs reform.

Assist on treasury management.

Advise on customs reform.

Advise on introduction of West African

Economic and Monetary Union

(WAEMU) common external tariff.

Advise on tax administration

Review progress in implementing tariff and

customs administration reforms and provide

advice on a strategy for the next steps.

Advise on budget and accounting

procedures as well as on government

financial information system

Advise the governor of the BCRG.

Advise on monetary operations

Examine foreign exchange auctions system at the BCRG.

Advise on liquidity forecasting, review

foreign exchange operations, and advise on supervisory framework for microfinance institutions.
1998-2000

\section{Timing}

March 1999

January-June 1999

Sep. 1999-Oct. 2000

September 2002

June 2004

December 2004

February 2005

June 21-30, 2000

October 10-24, 2000

End-November 2001

\footnotetext{
${ }^{4}$ This does not reflect continuing technical assistance provided since 2003 by the West AFRITAC resident experts.
} 
MFD

MFD

MFD

STA

STA
Advise on liquidity management

Advise on bank supervision.

Advise on bank liquidity management, exchange operations, and supervision

Examine the overall compilation of real sector statistics.

Review the coverage of the monetary Statistics, as well as data collection and compilation practices.
Nov.-Dec. 2002

March 2003

March 2004

Follow-up: September 2004

March 2000

November 2000

\section{Resident Representatives:}

Mr. Jones has been Resident Representative since July 2003. 


\section{Guinea: IMF-World Bank Relations}

(As of May 4th, 2005)

\section{Partnership in Guinea's Development Strategy}

1. Guinea's development strategy is laid out in the government's poverty reduction strategy paper (PRSP), which was endorsed by the Executive Board of the Bank on July $25^{\text {th }}, 2002$. The PRSP rests on three pillars: first, to foster sustainable growth, and create income-earning and employment opportunities, particularly for the rural poor; second, to extend access to basic services and improve their quality; and third, to improve governance and strengthen institutional and human capacity. The PRSP builds on Guinea's poverty reduction policies as formulated in the "Guinea-Vision 2010" document of December 1996 and the interim PRSP of 2000.

2. The Fund and the World Bank cooperate closely, within their respective mandates, in assisting the government to implement its medium-term poverty reduction and growth strategy. The Fund leads the policy dialogue on macroeconomic policies. The World Bank is taking the lead in areas of structural reforms, including banking sector restructuring; privatization in the telecommunication, electricity, and water sectors; administrative decentralization; judicial reform, capacity building; health, education, rural development, road maintenance; and on governance issues.

\section{Bank Group Country Assistance Strategy}

3. The current Country Assistance Strategy (CAS 2004-06) for Guinea was approved by the Board in June 2003. The CAS presents three scenarios. In the high-case scenario, the Bank would increase budget support through the PRSC and provide project financing to the power and water sectors. The PRSC would provide an adequate time frame and resources for tackling medium- and long-term reforms in the key areas of decentralization, governance, and privatization of utilities (water, electricity and telecommunication. In the base case, the CAS would support key aspects of the PRSP and prepare the way for a new relationship with the development partners based on a gradual phasing in of programmatic lending, leading to more efficient allocation and utilization of external aid. Finally, the low-case scenario assumes government is unable to make significant progress in resolving key macroeconomic, fiscal and governance issues. Any assistance would be limited to safeguarding the progress achieved in the priority sectors, vital to poverty reduction. There would be no budget support, nor infrastructure financing.

4. IDA provided in 2001 a fourth Structural Adjustment Credit (SAC IV) to Guinea. The credit operation was to support the country's poverty reduction strategy in the areas of public expenditure management, governance, and public services delivery to the poor. The SAC IV has had a satisfactory impact on the country's macroeconomic performance. The credit was disbursed in one tranche (US\$50 million) on the grounds that, despite the lack of any external budget support for a two-year period, Guinea had kept its economy broadly on track and had 
demonstrated commitment to the program reforms with regard to public expenditure management, governance, and the decentralization of basic service delivery. The adjustment program supported by SAC IV paved the way for programmatic lending to support the government's poverty strategy through the preparation of a Poverty Reduction Support Credit (PRSC), originally scheduled for FY04. The PRSC preparation assumed continuing sound macroeconomic performance and reform implementation. However, macroeconomic management deteriorated seriously since mid-2002 and the Fund's PRGF supported program went off track in December 2002. Key contributing factors were overspending related to security outlays, a generally highly expansionary fiscal stance, lax monetary policies, and a fixing of the exchange rate, leading to rising inflation and a sharp decline in gross reserves. Structural reforms came also to a halt. The wavering macroeconomic policies, slow progress on structural reforms and governance, the risks to political stability, combined with exogenous shocks - lower prices for bauxite and other commodities-led to slow GDP growth in 2003 (1.2 percent) and 2004 (2.7 percent). Given the poor macroeconomic performance, Guinea qualifies currently only for the CAS' low-case lending scenario. Consequently, the Bank's support will be limited to protecting the sectors vital to poverty reduction.

5. As of end-April 2005, the IDA has approved 62 credits for Guinea, of which eleven were in the transport and infrastructure sector; thirteen in the energy, mining, water, and telecommunications sector; three in strengthening the country's management capability; five in public sector/governance; twelve in financing rural sector development; three in the urban sector; four in the health sector; seven in the education sector; one in social protection; three in the financial sector. The total value of these projects amounts to about US $\$ 1,445$ million equivalent, of which US\$1,311 million has been disbursed. During the period FY98-05, the Board approved two adjustment operations (Public Expenditure Management Adjustment Credit and the Fourth Structural Adjustment Credit) and 9 investment operations: the National Rural Infrastructure Project, Decentralized Rural Electrification, Education for All, Village Community Support Program, the Capacity Building for Service Delivery Program, the Microfinance LIL, the Pre-Service Teacher Education LIL, the Urban Project, and the Population and Reproductive Health Project. The Bank's current portfolio in Guinea reflects the priorities of the PRSP. It comprises eight projects totaling US\$236.6 million, of which US\$20.3 million is in the form of a grant, and US\$133.6 million remain undisbursed. The Capacity Building for Service Delivery Project (US\$19 million, with an undisbursed balance of $\$ 14.3$ million) which closed on June 30, 2004, was retroactively extended to May 31, 2005 in order to permit the financing of a forensic audit. The non lending program includes fiduciary assessment; a public expenditure review (PER); analysis of public finance management and audit systems; a cross-cutting assessment of Guinea's social, structural, and sector development under the PRSP; and Bank/Fund collaborative work on social impact analysis.

6. Under the current low-case CAS scenario, the proposed World Bank lending program for FY04-06 will support a National Rural Infrastructure Project (\$30.3 m) which was approved in August 2004 and a Second Health Sector Project (US\$25 million) scheduled for Board in early June 2005; a Second Village Community Support Program (US\$45 million) is 
included in FY06. A second phase of the Urban APL in FY07(S) could be advanced if Guinea moves up to the base case.

\section{Bank-Fund Collaboration in Specific Areas}

7. The IMF and World Bank staffs maintain a collaborative relationship in supporting the government's poverty reduction strategy and structural reforms. As part of its overall assistance to Guinea through lending, country analytic work, and technical assistance, the Bank supports policy reforms in the following areas in collaboration with the Fund.

\section{Public Expenditure Management}

8. Improvements in public expenditure management have been one of the priorities of the Guinean government since 1996. The Bank, the Fund, and other donors have worked closely to provide the government with the needed support for institutional and policy reforms. While the Fund is leading the dialogue on tax policy, the Bank is focusing on strategic resource allocation and operational efficiency of public expenditures. To enhance strategic resource allocation and operational efficiency, the Bank has assisted the government in the preparation of the medium-term expenditure framework (MTEF) and is supporting the strengthening of the budget process as well as the allocation of resources to pro-poor priority areas at the decentralized level. A Country Procurement Assessment Review (CPAR) was undertaken in 2002 and a Public Expenditure Review (PER) followed in 2004. The PER was managed by the Bank, enjoyed strong government ownership, and benefited from extensive consultation of beneficiaries and development partners in close collaboration with the Fund and the AfDB. The PER was complemented by a full Country Financial Accountability Assessment (CFAA) which focused on public expenditure management systems, the auditing of public finances and related governance issues.

\section{Poverty and Social Impact Analysis}

9. The Bank and Fund's respective Guinea country teams are currently discussing the Poverty and Social Impact Analysis. It is envisaged that a few selected areas may be analyzed over the coming years. These might cover: an analysis of the impact on social output indicators of government spending in health and education, an assessment of the impact of the adoption of the Common External Tariff of the West African Economic and Monetary Union (WAEMU) on the taxation of basic consumer goods, an assessment of the impact of exchange rate flexibility on consumer prices, a social impact analysis of trade reforms, and an analysis of the impact of taxation on growth and income distribution. The selection of the few reforms to analyze will be based on the importance of the expected poverty and social impacts of each reform, the prominence of the issue in the government's agenda, the timing and urgency of the reform, and the level of national debate surrounding the reform. The 2003 household survey will be completed during the first semester of 2005, making it possible to better identify key determinants of poverty and their interdependency and track poverty impact over time. 


\section{Public Service Reform and Improved Service Delivery}

10. In recent years, the Government of Guinea, with the support of the Bank and other donors, has launched a number of initiatives to improve administrative performance and to foster greater accountability, transparency, and integrity in the public sector. The Bank supported these efforts through : (i) the Economic Management Technical Assistance Project between 1993 and 2000 (Projet d'Appui à la Gestion Economique et Financière - PAGE), (ii) the Capacity Building for Service Delivery Project from 2000-2004 (Projet de Renforcement des Capacités Institutionelles Pour une Meilleure Prestation des Services $P R C I$ ), (iii) governance and corruption surveys launched by the former Anti-Corruption Commission (Conseil National de Lutte contre la Corruption - CNLC) and (iv) a grant to strengthen the capacity of the Finance Committee of the National Assembly and the Chamber of Accounts.

11. These reforms aim to improve service delivery and financial accountability through capacity building and support to the Government's decentralization process. However, the impact of PAGE on public service efficiency and effectiveness was limited and the PRCI was suspended in August 2003 because of corruption, leaving most of the project's results indicators unachieved. In contrast, evaluation of the corruption surveys is ongoing and progress has been made in strengthening the capacity of the Parliament's Finance Committee and the Chamber of Accounts.

12. Cooperation between the Bank and the Fund covers those areas where public sector reform has a direct impact on fiscal stability and public sector financial management.

\section{Trade Reforms}

13. The Bank and the Fund also are working together closely to assist Guinea in establishing a pro-growth trade framework. While the Fund has taken the lead in reforms in the tariff regime, the Bank is trying to foster trade through the Integrated Trade Framework. The Bank is also involved in a dialogue on trade reforms in the context of the WAEMU at the regional level.

World Bank Contact Person: Mr. Wilfried Engelke (Phone: 473-2062). 
World Bank Loan and Grant Operations, 1999-2005

(In millions of U.S. dollars)

\begin{tabular}{|c|c|c|c|c|c|c|c|}
\hline & 1999 & 2000 & 2001 & 2002 & 2003 & 2004 & 2005 \\
\hline & Actual & Actual & Actual & Actual & Actual & Actual & Proj. \\
\hline $\begin{array}{l}\text { I. Project Credit Disbursements } \\
\text { Established Operations }\end{array}$ & 31.0 & 29.0 & 27.0 & $\mathbf{3 0 . 0}$ & 27.0 & 40.6 & 23.0 \\
\hline Power II $(7 / 92)^{2}$ & 1.0 & 0.0 & 0.0 & 0.0 & 0.0 & 0.0 & 0.0 \\
\hline Water II $(2 / 89)$ & 0.0 & 0.0 & 0.0 & 0.0 & 0.0 & 0.0 & 0.0 \\
\hline Highways IV (6/88) & 0.0 & 0.0 & 0.0 & 0.0 & 0.0 & 0.0 & 0.0 \\
\hline Agric. Seeds (12/87) & 0.0 & 0.0 & 0.0 & 0.0 & 0.0 & 0.0 & 0.0 \\
\hline Transport Sector (6/87) & 0.0 & 0.0 & 0.0 & 0.0 & 0.0 & 0.0 & 0.0 \\
\hline Forestry \& Fishery M (10/89) & 0.0 & 0.0 & 0.0 & 0.0 & 0.0 & 0.0 & 0.0 \\
\hline Population \& Health (7/87) & 0.0 & 0.0 & 0.0 & 0.0 & 0.0 & 0.0 & 0.0 \\
\hline Telecommunications $(12 / 92)^{2}$ & 0.0 & 0.0 & 0.0 & 0.0 & 0.0 & 0.0 & 0.0 \\
\hline Second ECN Management Support (11/88) & 0.0 & 0.0 & 0.0 & 0.0 & 0.0 & 0.0 & 0.0 \\
\hline Second Urban $(3 / 90)^{2}$ & 1.0 & 0.0 & 0.0 & 0.0 & 0.0 & 0.0 & 0.0 \\
\hline Research Extension $(9 / 88)$ & 0.0 & 0.0 & 0.0 & 0.0 & 0.0 & 0.0 & 0.0 \\
\hline National Rural Infrastructure $(3 / 90)^{2}$ & 0.0 & 0.0 & 0.0 & 0.0 & 0.0 & 0.0 & 0.0 \\
\hline Agriculture Export Promotion $(7 / 92)^{2}$ & 1.0 & 2.0 & 1.0 & 2.0 & 2.0 & 0.0 & 0.0 \\
\hline Health Nutrition Sector Project $(3 / 94)^{2}$ & 4.0 & 2.0 & 4.0 & 4.0 & 0.1 & 0.0 & 0.0 \\
\hline $\operatorname{SDA}(3 / 89)$ & 0.0 & 0.0 & 0.0 & 0.0 & 0.0 & 0.0 & 0.0 \\
\hline Urban III (4/99) & 0.0 & 1.0 & 2.0 & 2.0 & 1.8 & 4.5 & 2.0 \\
\hline Third Water Supply (4/97) & 1.0 & 4.0 & 3.0 & 1.0 & 8.4 & 15.4 & 9.0 \\
\hline Min. Sector Investment Promotion $(6 / 96)^{2}$ & 3.0 & 2.0 & 1.0 & 0.0 & 0.0 & 0.0 & 0.0 \\
\hline Agricultural Services SIL (F96) $(4 / 96)^{2}$ & 9.0 & 8.0 & 3.0 & 0.0 & 0.0 & 0.0 & 0.0 \\
\hline Public Entreprise Reform $(6 / 92)^{2}$ & 0.0 & 0.0 & 0.0 & 0.0 & 0.0 & 0.0 & 0.0 \\
\hline Equity and School Improvement $(5 / 95)^{2}$ & 8.0 & 5.0 & 3.0 & 7.0 & 1.9 & 0.0 & 0.0 \\
\hline Higher Education Management $(11 / 95)^{2}$ & 1.0 & 1.0 & 1.0 & 1.0 & 0.0 & 0.0 & 0.0 \\
\hline Population \& Reprod. Health $(12 / 98)^{2}$ & 1.0 & 2.0 & 4.0 & 3.0 & 1.3 & 0.3 & 0.0 \\
\hline Pre-Service Teacher Education $(7 / 98)^{2}$ & 1.0 & 1.0 & 1.0 & 1.0 & 0.0 & 0.0 & 0.0 \\
\hline Service Delivery CB APL $(12 / 99)^{2}$ & 0.0 & 0.0 & 2.0 & 2.0 & 2.2 & 0.0 & 0.0 \\
\hline Education for All $(7 / 01)$ & 0.0 & 0.0 & 0.0 & 4.0 & 2.2 & 12.7 & 6.0 \\
\hline Village Community Support Program APL (2/99) & 0.0 & 1.0 & 2.0 & 3.0 & 5.3 & 5.8 & 2.0 \\
\hline Multi-Sectoral AIDS Project (12/02) & 0.0 & 0.0 & 0.0 & 0.0 & 1.7 & 1.3 & 3.0 \\
\hline Decentralized Rural Electrification (7/02) & 0.0 & 0.0 & 0.0 & 0.0 & 0.0 & 0.7 & 1.0 \\
\hline II. Adjustement Operations & 26.0 & $\mathbf{0 . 0}$ & $\mathbf{0 . 0}$ & 49.0 & 0.4 & $\mathbf{0 . 0}$ & $\mathbf{0 . 0}$ \\
\hline Sal I $(2 / 86)$ & 0.0 & 0.0 & 0.0 & 0.0 & 0.0 & 0.0 & 0.0 \\
\hline Education Sector Adjustment Program $(6 / 90)^{2}$ & 0.0 & 0.0 & 0.0 & 0.0 & 0.0 & 0.0 & 0.0 \\
\hline Private Sector Promotion $(5 / 90)^{2}$ & 0.0 & 0.0 & 0.0 & 0.0 & 0.0 & 0.0 & 0.0 \\
\hline Sal II $(6 / 88)$ & 0.0 & 0.0 & 0.0 & 0.0 & 0.0 & 0.0 & 0.0 \\
\hline Financial Sector $(10 / 94)^{2}$ & 1.0 & 0.0 & 0.0 & 0.0 & 0.0 & 0.0 & 0.0 \\
\hline Public Expenditure Management Adjustement Credit $(12 / 97)^{2}$ & 25.0 & 0.0 & 0.0 & 0.0 & 0.0 & 0.0 & 0.0 \\
\hline $\operatorname{Sac}$ IV $(07 / 01)^{2}$ & 0.0 & 0.0 & 0.0 & 49.0 & 0.4 & 0.0 & 0.0 \\
\hline III. IFC Project Portfolio & 0.0 & 0.0 & 0.0 & 0.0 & 0.0 & 0.0 & 0.0 \\
\hline IV. MIGA Guarantees & & & 51.5 & 39.4 & 17.5 & 15.7 & $\ldots$ \\
\hline
\end{tabular}

${ }^{1}$ Date of Board approval in brackets.

${ }^{2}$ Closed. 